Adilhan ADİLOGLU
Dr. Öğr. Üyesi | Assist. Prof. Dr.
Akdeniz Üniversitesi, Edebiyat Fakültesi Türk Dili ve Edebiyatı Bölümü, Antalya-TÜRKIYE
Akdeniz University, Faculty of Letters, Department of Turkish Language and Literature, Antalya-TURKEY
ORCID: 0000-0002-7317-1500
adilhanadiloglu@hotmail.com

\title{
Sovyet Propagandası Çerçevesinde İkinci Dünya Savaşı'nın Karaçay-Malkar Edebiyatındaki Yansımaları
}

$\ddot{O} z$

Bu çalışmada; Rusya ve eski SSCB ülkelerinin "Büyük Vatan Savaşı" şeklinde adlandırdığı, 1941-1945 yılları arasında, bilhassa Nazi Almanya'sına karşı topraklarını savundukları, İkinci Dünya Savaşı'nın Sovyet edebiyatı sahasındaki tesiri ve buna bağlı olarak da Karaçay-Malkar edebiyatındaki yansımaları ele alınmıştır. Sovyetler Birliği, İkinci Dünya Savaşı'na katılma arifesinde orduyu ve ekonomiyi savaş için örgütlemek, hâkimiyetindeki milletlerin maddî ve manevî desteğini almak maksadıyla yoğun bir şekilde gerçekleştirdiği propaganda faaliyetleri çerçevesinde edebiyat sahasını etkin bir şekilde kullanmıştır. Sovyet rejimi taraftarı şair ve yazarlar ile birlikte Stalin yönetimi sırasında susturulan edebiyatçılar dahi "vatan toprakları tehlike altında" gerekçesiyle bilhassa yurttaşlık duygularını uyandırmak ve kuvvetlendirmek yoluyla, halkın moralini yüksek tutmak ve cesaret vermek için göreve çağrılmışlardır. Sovyetler Birliği bünyesindeki diğer milletlerde olduğu gibi, Karaçay-Malkar Türklerinin edebiyatında da "Ullu Ata Curt Kazavat" (Büyük Vatan Savaşı) teması önemli bir yer tutmaktadır. Dönemin şartlarına ve Sovyet yetkililerinin verdiği direktiflere uygun olarak, 1930'lu yılların sonlarından itibaren bütün KaraçayMalkar şair ve yazarları eserlerinde Sovyet vatanının sarsılmaz gücünü ve yenilmezliğini işlemekte, vatana karşı gelebilecek tehlikelere karşı halkı uyarmakta ve gerektiğinde bütün halkı vatan için canlarını feda etmeye davet etmektedirler.

Anahtar Kelimeler: İkinci Dünya Savaşı, Sovyet Propagandası, Sovyet Edebiyatı, Karaçay-Malkar Edebiyatı.

\section{Reflections of Second World War in the Karachay-Balkar Literature within the frame of Soviet Propaganda}

\begin{abstract}
This study deals with the effects of Second World War, which is called "The Great Patriotic War" by Russia and Ex-Soviet countries that defended their lands especially against Nazi Germany between 1941 and 1945, on Soviet literature and correspondingly its reflections on Karachay-Balkar literature. On the eve of going to the Second World War, Soviet Union has used literature very effectively in the context of propaganda activities in order to organize the army and the economy for the war and acquire the material and spiritual support of the nations in the union. Pro-Soviet regime poets and writers even the literati who were squelched during Stalin's administration were called for duty by the reason that "motherland is in danger" so as to stir and strengthen especially citizenship feelings and keep public morale high and encourage people. The theme of "The Great Homeland War" has an important place in the literature of Karachay-Balkar Turks like all other nations in the Soviet Union. Starting from the end of the 1930s, all Karachay-Balkar poets and writers have discussed the unshaken power and invincibility of Soviet motherland in their works, warned the people against the dangers to the motherland and invited them to sacrifice their lives for the motherland if required in accordance with the period's conditions and instructions, given by Soviet officers.
\end{abstract}

Keywords: Second World War, Soviet Propaganda, Soviet Literature, Karachay-Balkar Literature. 


\section{Adilhan ADİLOĞLU, "Sovyet Propagandası Çerçevesinde İkinci Dünya Savaşı’nın Karaçay-Malkar Edebiyatındaki Yansımaları”, Mavi Atlas, 7(1)/2019: 16-51.}

\section{Giriş}

İnsanlık tarihinin en büyük ve en kanlı savaşı olarak kabul edilen İkinci Dünya Savaşı'na elliden fazla devlet katılmış, yüz milyondan fazla askerî, bir o kadar da sivil personel dâhil olmuştur. Savaşa katılan devletlerin bütün askerî ve sivil güçleri ile ekonomik ve endüstriyel kaynaklarını seferber ettiği bu savaşın sonuçları çok ağır ve yıkıcı olmuştur. $\mathrm{Bu}$ savaşta yetmiş milyondan fazla insan hayatını kaybetmiştir. Bu sayının neredeyse yarısının; yaklaşık otuz milyon insanın, eski Sovyetler Birliği vatandaşı olduğu tahmin edilmektedir. Dolayısıyla diğer devletlere göre eski SSCB'de bu savaşın etkileri ve sonuçları çok daha derin ve ağır olmuştur.

Bilindiği üzere 1914-1918 yılları arasında cereyan eden Birinci Dünya Savaşı'ndan sonra yapılan siyasî, idarî, iktisadî ve hukukî antlaşmalardan doğan memnuniyetsizlikler yakın gelecekte gerçekleşmesi muhtemel yeni bir büyük dünya savaşının habercisi niteliğindeydi. Mevcut durumdan memnun olmayan Almanya, İtalya ve Japonya gibi devletler uluslararası dengelerin kendi lehlerine değiştirilmesi yönündeki taleplerini sürekli dile getirmekteydiler. Bu sebeple bu üç devlet kendi aralarında anlaşarak "Mihver Devletleri” grubunu oluşturarak, çevrelerindeki ülkelere karş1 saldırgan tavırlar içerisine girmişlerdir. Müteakiben; Japonya 18 Eylül 1931 tarihinde Mançurya'yı işgal etmiş, 7 Temmuz 1937 tarihinde de Çin'i istila ederek bir anlamda Pasifik havzasında İkinci Dünya Savaşı'nı başlatmıştır. Avrupa kıtasında ise İtalya 2 Ekim 1935 tarihinde Etiyopya'y1, 15 Nisan 1939 tarihinde de Arnavutluk'u ele geçirmiştir. Ve nihayet, Almanya 1 Eylül 1939 tarihinde Polonya'yı işgal etmiş ve fiilen İkinci Dünya Savaşı'nı başlatmıştır. Çok geçmeden 3 Eylül 1939 tarihinde de İngiltere ile Fransa da, Almanya'ya karşı savaş ilan etmişlerdir (Hart, 2015: 21).

İkinci Dünya Savaşı'nın başlamasından kısa bir süre önce, Almanya ile Soyvetler Birliği arasında 23 Ağustos 1939 tarihinde gizli bir "saldırmazlık anlaşması" yapılmıştır. $\mathrm{Bu}$ anlaşma aslında iki ülkenin Doğu Avrupa'yı paylaşma anlaşmasıdır. Nitekim Almanya'nın Polonya'yı işgal etmesini müteakip, Sovyetler Birliği de payını almak için 17 Eylül 1939 tarihinde doğrudan Polonya'ya saldırmıştır. Neticede Almanya ve Sovyetler Birliği, 29 Eylül 1939 tarihinde Polonya'yı tam bir hâkimiyet altına alarak kendi aralarında bölüşmüşlerdir. Bilahare, Sovyetler Birliği 12 Mart 1940 tarihinde Finlandiya'yı, 28 Haziran 1940 tarihinde Romanya'yı işgal etmiş, 6 Ağustos 1940 tarihinde de Baltık devletlerini kendi topraklarına katmıştır (Armaoğlu, 1999: 185). Böylelikle Sovyetler Birliği, Almanya'nın taarruzundan önce, bütün dünyaya sözde "sömürü düzeninin karşısında olduğunu" resmî devlet ideolojisi olarak takdim ederken, 


\section{Adilhan ADİLOĞLU, "Sovyet Propagandası Çerçevesinde İkinci Dünya Savaşı’nın Karaçay-Malkar Edebiyatındaki Yansımaları”, Mavi Atlas, 7(1)/2019: 16-51.}

her ne kadar Mihver Devletleri içerisinde yer almasa da, en az onlar kadar saldırgan, işgalci ve emperyalist bir devlet olduğunu tüm dünyaya göstermiştir.

Almanya, gizli “saldırmazlık anlaşması"na rağmen, 22 Haziran 1941 tarihinde ani ve hızlı bir şekilde taarruza geçerek SSCB topraklarını işgal etmeye başlamıştır. Sovyetler Birliği böyle bir saldırıyı beklemediği için hazırlıksız yakalanmış, bu yüzden de Almanlar kısa bir süre içerisinde Leningrad-Moskova-Rostov havzasını hâkimiyet altına almışlardır. Ancak bir süre sonra toparlanarak direnişe geçen Sovyet ordusu 6 Aralık 1941 tarihinde başlattığı karşı taarruzla Moskova'yı Almanlardan geri almıştır. Bunun üzerine Almanlar güneye doğru çekilerek Stalingrad ve Kafkasya bölgesine yönelmişlerdir (Hart, 2015: 218).

Bütün Avrupa'da İkinci Dünya Savaşı'nın dönüm noktası olarak kabul edilen, 23 Ağustos 1942-2 Şubat 1943 tarihleri arasında cereyan eden meşhur Stalingrad Muharebesinden sonra savaştaki üstünlük SSCB'ye geçmiştir. Bu tarihten sonra Sovyet orduları taarruza geçmiş, Almanlar sürekli gerilemiştir. Nihayetinde 9 Mayıs 1945 tarihinde Nazi Almanyası kayıtsız şartsız teslim olmuş ve mağlubiyeti kabul etmiştir (Armaoğlu, 1999: 207).

Rusya ve eski Sovyetler Birliği ülkeleri tarafından "Büyük Vatan Savaşı” şeklinde adlandırılan, 1941-1945 yılları arasında, bilhassa Nazi Almanyasına karşı topraklarını savundukları İkinci Dünya Savaşı'nın Sovyet edebiyatı sahasındaki tesiri ve buna bağlı olarak da Karaçay-Malkar edebiyatındaki yansımaları oldukça kuvvetli olmuştur. Sovyet yetkilileri savaş döneminde yoğun şekilde gerçekleştirdikleri propaganda faaliyetleri çerçevesinde edebiyat sahasını da etkin bir şekilde kullanmışlardır. Sıklıkla "vatan toprakları tehlike altında" gerekçesiyle bilhassa yurttaşlık duygularını kuvvetlendirmek suretiyle halkın moralini yüksek tutmak ve cesaretlendirmek maksadıyla ülkedeki bütün şair ve yazarlar göreve çağrılmışlardır. Bu dönemde yaklaşık pek çok şair ve yazar gerek cephede ve gerekse cephe gerisinde kalemlerini adeta bir silah gibi kullanmak suretiyle Almanlara karşı büyük bir mücadele örneği sergilemişlerdir. Savaş sonrasında bunlardan yaklaşık beş yüz kadarına çeşitli madalyalar verilmiş, hata on kadarı da "Sovyetler Birliği Kahramanı" payesiyle taltif edilmiştir (Синявский, 1961: 5-6).

Dönemin en meşhur Sovyet-Rus yazar ve şairlerinden olan Aleksandır Tvardovskiy'nin Büyük Vatan Savaşının ansiklopedisi niteliğindeki "Vasiliy Terkin" adlı eseri, Aleksey Surkov'un "Zafer Yemini” ve "Sığınak" adlı eserleri, Rus millî marşının da bestecisi olan Aleksandr Aleksandrov tarafından bestelenerek bir savaş marşı haline getirilen Vasiliy Lebedev-Kumaç'ın meşhur "Kutsal Savaş” başlıklı şiiri, Nikolay Tihonov’un "Kirov Bizimle” ve "Kızıl Ordu” başlıklı şiirleri, Mihail Şolohov’un "Vatan 
için Savaştılar" adlı eseri, Konstantin Simonov'un "Bekle Beni”" adlı şiiri gibi bu dönemde ortaya konulan belli başlı eserlerde genellikle Kızıl Ordunun yenilmezliği, Sovyet askerlerinin cephedeki yiğitlikleri ve canlarını fedâ etmeleri, vb. konular ele alınmıştır (Къараланы-Борлакъланы, 1990: 32).

Sovyetler Birliği hâkimiyetindeki diğer milletlerde olduğu gibi, Karaçay-Malkar Türklerinin edebiyatında da "Ullu Ata Curt Kazavat" (Büyük Vatan Savaşı) teması önemli bir yer tutmaktadır. Dönemin şartlarına ve Sovyet yetkililerinin verdiği direktiflere uygun olarak, 1930'lu yılların sonlarından itibaren bütün Karaçay-Malkar şair ve yazarları eserlerinde Kızıl Ordunun sarsılmaz gücünü ve yenilmezliğini işlemekte, vatana karşı gelebilecek tehlikelere karşı halkı uyarmakta ve gerektiğinde bütün halkı vatan için canlarını fedâ etmeye davet etmektedirler. Velhasıl, İkinci Dünya Savaşı arifesinde, bütün Sovyetler Birliğinde olduğu gibi, Karaçay-Malkar edebiyatı sahasında da savaş hazırlıkları tamamlamış, bütün şair ve yazarlar vatanı korumaya hazır bir haldedir.

"Birinci Devre" şeklinde adlandırabileceğimiz ve aynı zamanda Sovyet rejiminin kuruluş yıllarında ön plana çıkmış olan İsa Karaköt, Davut Baykul, Muhammet Orus, Tohtar Borlak, Hasan Bostan ve Salih Hoçu gibi Karaçay-Malkar şair ve yazarları "kendi istekleriyle" savaşa katılarak muhtelif cephelerde Almanlara karşı Sovyet ordusu saflarında savaşırken hayatlarını kaybetmişılerdir. Müteakiben "İkinci Devre” olarak ve yine "kendi istekleriyle" savaşa katılan Osman Hubiy, Abdülkerim Baykul, Halimat Bayramuk, Kaysın Kuliy, Kerim Otar, Bert Gurtu, İbrahim Mamme, Safar Makit, Şaharbiy Ebze ve Azamat Süyünç gibi şair ve yazarların da pek çoğu savaştan elini, kolunu, bacağını, gözlerini veya başka bir organını kaybederek dönmüşlerdir (Къараланы-Борлакъланы, 1972: 5).

Savaşa katılan bu şair ve yazarlarla ilgili olarak sadece Karaçay-Malkar değil, Sovyet hâkimiyetindeki diğer Türk halklarının edebiyat tarihini ihtiva eden kitap ve makalelerde yer alan "kendi istekleriyle" şeklindeki bir ifadenin sürekli vurgulanması dikkat çekmektedir. Bunların bir kısmı Sovyet rejimine gerçekten inanmış kişiler olarak vatanı kurtarmak maksadıyla ve kendi istekleriyle savaşa katılmış olabilirler. Ancak tamamının bu arzu doğrultusunda ve kendi istekleriyle "ölmek üzere" cepheye gittiklerini düşünmek pek de inandırıcı değildir. Muhtemelen bir kısmının "mecburiyetten" yani Sovyet rejiminin savaş sonrasında kendilerine yapılacak kötü muameleden korktukları için; bir kısmının da, Kırgız edebiyat eleştirmeni Salican Cigitov’un da ifade ettiği gibi, bir şair ve yazar olarak, sadece mensubu olduğu halkın içerisinde değil, bütün Sovyet Birliği çapında tanınmak, meşhur olmak isteği doğrultusunda katılmış olabilecekleri 


\section{Adilhan ADİLOĞLU, "Sovyet Propagandası Çerçevesinde İkinci Dünya Savaşı'nın}

Karaçay-Malkar Edebiyatındaki Yansımaları”, Mavi Attas, 7(1)/2019: 16-51.

düşünülebilir (Cigitov, 2004: 5). Nitekim öyle de olmuştur. Savaştan sonra memleketlerine sağ dönebilen şair ve yazarların kimisi Sovyetler Birliği çapında büyük şöhrete ulaşmış, kimisi de Sovyet rejimi tarafindan el üstünde tutulmuş; hemen hepsi üst düzey makam ve mevkiilere getirilmiştir.

Sovyet yetkililerinin direktifleriyle, Karaçay-Malkar edebiyatında "Büyük Vatan Savaşı" teması, genel olarak Sovyet edebiyatıyla birlikte yol almıştır. Dönemin meşhur Sovyet-Rus şairlerinin eserleri Karaçay-Malkar şairlerine model olmuştur. Bu sebeple şekil ve muhteva bakımından bazı Sovyet-Rus şairlerinin eserleri ile Karaçay-Malkar şairlerinin eserleri arasında büyük benzerlikler vardır. Hatta bu eserlerin bazılarının başlıkları bile aynıdır. Meselâ Konstantin Simonov'un “Onu Öldür”, "Saldırı” ve Vera İnber'in "Düşmanı Yok Et", "Vatanımız” başlıklı şiirleri ile Karaçay-Malkar şairleri Kerim Otar'1n "Saldırı Öncesinde”, “Biz Yemin Ediyorduk”, Halimat Bayramuk'un “Biz Galip Geliriz”, Kaysın Kuliy’in “Savaş Arifesinde", "Yemin”, Davut Baykul'un "Yok Et Düşmanı Yerden, Gökten, Denizden” vb. başlıklı şiirleri neredeyse birbirlerinin aynısıdır (Толгуров, 1978: 33).

\section{Savaş Arifesinde: "İspanya İç Savaşı”" ve "Japonların Saldırısı"}

Birinci Dünya Savaşından sonra uluslararası sahada baş gösteren huzursuzluklar İspanya'yı da derinden etkilemiş, bilhassa ülke içerisindeki düzensizlikleri şiddetlendirmiş ve bir iç savaşın çıkmasına sebep olmuştur. 1936-1939 yılları arasında "Cumhuriyetçiler" ile "Milliyetçiler" arasında cereyan eden İspanya iç savaşı General Franco liderliğindeki milliyetçilerin galibiyetiyle sonuçlanmıştır. İspanya'da baş gösteren söz konusu bu iç savaşla Sovyetler Birliği, İtalya ve Almanya yakından ilgilenmişlerdir. Almanya ve İtalya, Milliyetçilerin lideri General Franco'nun emrine asker ve mühimmat gönderirken, buna karşılık Sovyetler Birliği de Cumhuriyetçilere destek vermiştir. Bir yandan SSCB'de İspanyol Cumhuriyetçileri lehine büyük gösteriler yapılırken, bir yandan da İspanya'daki Sovyet elçilik ve konsolosluk memurları Cumhuriyetçilere akı1 hocalığı yaparak onları yönlendirmeye çalışmışlardır (Armaoğlu, 1999: 137).

İspanya' da cereyan aden iç savaşın Sovyet basını ve edebiyat sahasına yansımaları da olmuştur. İspanya'daki iç savaşa bizzat katılan ve orada cereyan eden olayları Sovyet basınına aktaran İlya Ehrenburg'un (1891-1967) “İnsan Neye İhtiyaç Duyar” (1937) adlı roman1, Aleksandr Afinogenov'un (1904-1941) “Selam, İspanya!” (1936) adlı piyesi ve yine İspanya iç savaşı sırasında Pravda gazetesi muhabiri olarak görev yapan ve ayrıca SSCB'nin gayri resmî bir devlet yetkilisi olmak suretiyle Cumhuriyetçilerin safinda iç savaşta aktif olarak rol oynayan Mihail Koltsov’un (1898-1940) “İspanyol Günlüğü” 


\section{Adilhan ADİLOĞLU, "Sovyet Propagandası Çerçevesinde İkinci Dünya Savaşı'nın Karaçay-Malkar Edebiyatındaki Yansımaları”, Mavi Attas, 7(1)/2019: 16-51.}

(1938) adlı eseri, Sovyetler Birliğinde ve diğer Doğu Bloku ülkelerinde büyük yank1 bulmuştur (Къараланы, 1978: 198).

İspanya iç savaşı elbette Sovyet edebiyatıyla paralel olarak Karaçay-Malkar edebiyatına da yansımıştır. Mesela ilk olarak o dönemde edebiyat sahasına yeni girmeye başlayan Halimat Bayramuk'un (1917-1996) "Dolores İbarruri” adlı eseri epeyce bir ses getirmiştir. Şairin 1936 yılında "Kızıl Karaçay” gazetesinde yayımlanan bu şiiri, İspanya iç savaşına aktif olarak katılan meşhur Cumhruriyetçi liderlerden Bask kökenli İspanyol komünist siyasetçi ve yazar Dolores İbarruri (1895-1989) hakkındadır. Karaçay şairi Halimat Bayramuk bilâhare, İspanya iç savaşını Milliyetçilerin kazanması üzerine Sovyetler Birliğine iltica eden Dolores İbarruri ile Moskova'da bir araya gelerek görüşmüştür (Байрамукъланы, 2008: 492).

Karaçay-Malkar edebiyatında İspanya iç savaşıyla ilgili olarak asıl ses getiren eserler, Sovyet rejiminin yetiştirdiği en önemli Karaçay şairlerinden biri olan Davut Baykul (1902-1942) tarafından verilmiştir. Şairin İspanya iç savaşıyla ilgili yazdı̆̆ eserleri arasında "İspan Kızçık" (İspanyol Kız Çocuğu) başlıklı şiiri en meşhur olanıdır. Şair bu eserinde İspanya iç savaşında Milliyetçilere karşı mücade eden Cumhuriyetçilerin direnişini, yiğitliklerini ve kahramanlıklarını coşkulu bir dille ifade ederken, ayrıca bütün dünyada ezilen ve tahakküm altında olan proleter zümrelerin birleşmesi gerektiğini de vurgulamaktadır. Eserin en dikkat çeken bölümü, Milliyetçilerin türlü türlü zulümlerine maruz kalan Cumhuriyetçilerin safında mücadele eden bir kadının, on üç yaşındaki küçük kızının gözleri önünde acımasız bir şekilde öldürülmesi kısmıdır. Küçük kız çocuğu bir taraftan annesinin kanlı bedenine sarılarak ağlarken, bir taraftan da intikam duygusuyla ve cesur bir şekilde, annesinin katillerinin yüzlerine karşı, babası tarafından annesinin öcünün alınacağını haykırmaktadır. Şair böylelikle savaşın çocukların üzerindeki etkisini öne çıkarılmak suretiyle, İspanya iç savaşında Franco kuvvetlerinin Cumhuriyetçilere yaptıkları zulmü vurgulanmaktadır (Байкъулланы, 1959: 20):

İspan halknı kerti caşını kızıma

Meni atam respublikan askerdi

Ma bu meni tabhan anamdi

Sizge cavluk etgendi bügüñ̃̃e deri

Bügün ölgendi sizni koluğuzdan

Anı kanın atam alır barığızdan.
İspanyol halkının yiğit oğlunun kızıyım Benim babam Cumhuriyetçi askeridir İște bu da beni doğuran annemdir Size karşı savaştı bugüne kadar Bugün ölmüştür sizin elinizden Onun kanını babam alır hepinizden.

İspanya iç savaşıyla ilgili olarak yine bu dönemde edebiyat sahasına yeni girmeye başlayan Tohtar Borlak’ın (1914-1942) “İspan Caşçık” (İspanyol Çocuk) başlıklı şiirinde de benzer bir şekilde, Milliyetçiler ile Cumhuriyetçilerin çatışmaları sırasında anne ve 
babasını kaybeden bir İspanyol çocuğun acıklı durumu dramatize edilmektedir. Esere konu olan İspanyol çocuk, soğuk bir kış gecesi, üç gün boyunca aç ve susuz kalmış halde iken bir evin kapısını çalar. Ancak, kapıyı açan bir Franco askeridir ve çocuğun yüzüne sert bir tekme vurup kapıyı kapatır. Yere yığılan çocuk bir süre annesini hayal ederek ağladıktan sonra can verir (Борлакъланы, 1939: 12). Bir önceki şiirde olduğu gibi bu şiirde de küçük bir çocuğun masumiyeti üzerinden insanların duygularını manipüle etme söz konusudur:

Açı suvuk sanların buzlatıb

Caşçık cerni tırnab kerildi, sozuldu

Oy anam, kabiriñda koynuña al deb

Anası közünden ketmey, sözü tıyıldı

Tañ atdı kaşların hını tüyüb

Kün da mıdahlanıb tavlanı carıtdı

Kanlı faşist caşçıknı arbazda tabıb

Ölükçüknü bağuşha atd1.
Keskin soğuktan bedeni donan Çocuk yeri tırmalayıp gerildi, kasıldı Ah annem, mezarında koynuna al diye Annesini hayal ederek, sesi kesildi

Gün ağardı kaşlarını çatarak Güneş de hüzünlenip dağları aydınlattı Kanlı faşist çocuğu avluda bulup Küçük cansız bedeni çöplüğe att1.

İkinci Dünya Savaşı arifesinde bir de Japonlar ile Sovyetler Birliği arasında bir dizi sınır çatışması yaşanmıştır. 1938-1939 yılları arasında cereyan eden bu çatışmaların önemli olanlarından biri de Hasan Gölü Muharebesidir. Sovyetler Birliğinin doğu sınırında Vladivostok şehrine yakın Hasan Gölü civarında 1938 yılının 29 Temmuz-11 Ağustos günlerinde meydana gelen bu çatışma Japonların saldırısıyla başlamıştır. Ancak, Sovyetler Birliği, Japonların bu saldırısına karşılık daha güçlü bir orduyla taarruz ederek bu çatışmadan galip çıkmıştır. Bu çatışmada her iki taraf da ağır kayıplar vermiştir. Fakat Sovyetlerin kaybı Japonlardan üç kat daha fazla olmuştur. Böylece Sovyetlerin insan unsuruna verdiği "değer" ölüçüsü ilk defa bu çatışmayla gün yüzüne çıkmıştır. Ancak bu durum Sovyet edebiyat sahasına farklı şekilde yansıtılmıştır. Bu temaya ilişkin verilen eserlerde genellikle Sovyet askerlerinin Hasan Gölü Muharebesinde Japon askerlerine karşı gösterdikleri kahramanlıkları anlatılırken, Sovyet ordusunun yenilmezliği vurgulanmaktadır. Meselâ, Davut Baykul'un "Hasannı Tulparlarına” (Hasan Gölünün Yiğitlerine) adlı eserinde Sovyet ordusunun tahrip gücünden övgüyle bahsedilmektedir (Байкъулланы, 1959: 20):

Gürüldey kurç samoletle baradıla

Kanlı cavnu töppesinde kathanlay

Üslerine korğaşınla cavadıla

Cayğ 1 künde katı buzla cavğanlay

Tankala da baradıla uluğanlay

Taş-tav, tob da tıyalmadı alların

Karşçılanıb süññüleni burğanlay

Avladıla Hasan kölnü cağaların.
Gürüldeyerek çelik uçaklar gidiyor

Kanlı düşmanın tepesinde odaklanıp

Üzerlerine kurşunları yağdırıyor

Sanki yaz gününde dolu yağıyor

Tanklar da gidiyor uğuldayarak

Dağ taş, toplar da kesemedi önlerini

Karşı durup süngüleri çevirince

Aldılar Hasan gölünün yakalarını. 
Yine aynı muharebeyle ilgili olarak Tohtar Borlak'ın "Lötçikni Cırı” (Pilotun Türküsü) adlı eserinde de Sovyet hava gücünün üstünlüğü ve pilotların kahramanlığ anlatılmaktadır (Акбаев vd., 1965: 261):

\author{
Kurç kuşumu ot cüregi tebedi \\ Propelleri hoynuh kibik katadı \\ Süt uyuğança turğan bulutlanı \\ Kippa kıppa, s1lıb s1lıb atadı \\ Yapon samuray cayak etin aşaydı \\ Kanlı suvsabdan kurğaksıb avuzu \\ Ol hamhot ursa, caññidan cavudururma \\ Hasan kölnü korğaşın caññurun.
}

Çelik kuşumun ateş yüreği çarpıyor

Pervaneleri topaç gibi dönüyor

Mayalanmış süt gibi duran bulutları

Yumak yumak, kesip kesip dağıtıyor
Japon samuray yanaklarını isırıyor
Kanlı içkiden içerek kurumuş ağzı
O suratını gösterirse yine yağdırırım
Hasan gölüne kurşun yağmurunu.

\section{3. İkinci Dünya Savaşı'nın Başlamasıı ve Caydırıcı Güç: "Yenilmez Kızıl Ordu"}

Almanya'nın Polonya'yı işgal etmesi üzerine, İngiltere ile Fransa da Almanya'ya karşı savaş ilan etmiş ve böylece Avrupa kıtasında İkinci Dünya Savaşı resmen başlamıştır. Bu arada Sovyetler Birliği de bir taraftan sessiz sedasız bir şekilde Polonya, Romanya, Finlandiya ve Baltık devletlerini işgal ederek kendi topraklarına katarken, bir taraftan da Almanya ile gizli bir saldırmazlık anlaşması yapmasına rağmen Almanların kendilerine de saldırabileceği endişesiyle bir telaş ve tedirginlik haline girmiştir. Bu sebeple içte ve dişta "dosta ve düşmana karşı” sahip olduğu askerî gücünü göstermek için süratle propaganda faaliyetlerine başlamıştır.

Birinci Dünya savaşından sonra başta Sovyetler Birliği olmak üzere dünyadaki belli başlı büyük devletler yeni bir savaş ihtimaline karşı süratle silahlanmaya başlamışlardı. Bu aynı zamanda her bir devletin kendisine dışarıdan gelebilecek saldırılara karşı bir korkutma ve caydırma siyasetidir. Bir devletin, diğer bir devletlete karşı, üstün silahlarla donatılmış kuvvetli bir orduya sahip olduğunu göstermesi, karşıdan gelecek her türlü tehdite karşı önceden önlem alma maksadıyla yapılmış bir propaganda faaliyetidir. Bu aynı zamanda içeride de kendi vatandaşı nezdinde bir güven ve gurur vesilesidir. Ayrıca vatadaşın devletine karşı mensubiyet ve sadakat hislerini kuvvetlendirir. Sovyetler Birliği bu propagandayı "Kızıl Ordu" vasıtasılla hem içeride, hem de dışarıda yoğun ve başarılı bir şekilde icra eden ülkelerin başında gelmektedir. Ruslar gerek askerî gösteri ve törenler yoluyla, gerekse işitsel, görsel ve yazılı basın yoluyla başarılı bir şekilde gerçekleştirdikleri bu yöndeki propaganda faaliyetlerini edebiyat sahasına da taşımışlardır. 


\section{Adilhan ADİLOĞLU, “Sovyet Propagandası Çerçevesinde İkinci Dünya Savaşı'nın Karaçay-Malkar Edebiyatındaki Yansımaları”, Mavi Atlas, 7(1)/2019: 16-51.}

Avrupa kıtasında İkinci Dünya Savaşı'nı resmen başlamasıyla birlikte Sovyet basınında ve edebiyat sahasındaki en önemli konu "Yenilmez Kızıl Ordu" temas1 olmuştur. Başta Nikolay Tihonov’un “Kızıl Ordu” başlıklı şiiri olmak üzere (Тихонов, 1943: 5), Vera İnber'in “Kızıl Asker” başlıklı şiiri (Инбер, 1954: 198), yine Aleksandr Prokofev' in "Kızıl Ordu Yürüyor” ile Vladimir Lifşits'in “Ordunun Yolu” başlıklı şiirleri bu temanın en bilinen örneklerindendir (Яцынов, 1943: 41, 46). Komünist Partinin direktifiyle, bu propaganda şiirlerinin benzerleri, Sovyet hâkimiyetindeki Rus olmayan milletlerin dillerinde de kaleme alınmıştır. Bu şiirler, Rus şairlerinin eserleriyle hemen hemen aynıdır, hatta onların kopyasıdır dersek abartmış olmayız. Meselâ Karaçay şairi Abdülkerim Batça'nın (1902-1935) Sovyet ordusuna adeta bir methiye niteliğini taşıyan “Kızıl Asker” başlıklı şiiri bunlardan biridir. Şair eserinde Kızıl Ordunun üstünlüğünü ve yenilmezliğini coşkulu bir şekilde dile getirmektedir. Bu şiir bilâhare bestelenerek bir Sovyet marşı haline getirilmiştir (Акбаев vd., 1965: 217):

Suvda cüzüb, cerde cürüb, tobla atabız Kuşla kibik kökde uçub, otla çaçabız Tuçdan okla, kurç kılıçla baylab biz belge

Duniya zalimlikni ezib, kömebiz cerge

Cer carılıb, ot çaçılsa, bir korkuv salmaz Sav duniyada, bir asker da bizge teñ bolmaz $\mathrm{Bu}$ berilgen erkinlikni bizden kişi almaz Ma biz Kızıl askerni asker horlamaz.
Suda yüzüp, yerde yürüyüp, toplar atıyoruz Kuşlar gibi gökte uçup, ateşler saçıyoruz Tunç okları, çelik kılıçları kuşanıp biz bele Dünyadaki zalimliği ezip, gömüyoruz yere

Yer yarılıp, ateş saçılsa, bir korku veremez Bütün dünyada, bir asker bile bize denk olamaz $\mathrm{Bu}$ verilen özgürlüğü bizden kimse alamaz İşte bu bizim Kızıl Ordu’yu hiçbir ordu yenemez.

Yine kendi isteğiyle Kızıl Orduya yazılarak savaşa katılan ilk devre Karaçay şairlerinden Hasan Bostan (1905-1942) da, iki ağabeyi ile birlikte, Sovyet ordusu saflarında Almanlara karşı savaşırken genç yaşta hayatını kaybetmiştir. Edebiyat sahasına yeni girmeye başlayan Hasan Bostan "Horlanmazlık Kızıl Asker" (Yenilmez Kızıl Ordu) başlıklı şiirinde, Kızıl Ordunun sahip olduğu gücünden bahisle, vatan topraklarına göz diken düşmanların paramparça edileceğini söylemekte, böylelikle Kızıl Ordunun üstün gücü ve yenilmezliğini vurgulamak suretiyle bütün dünyaya savaşa hazır olduklarını ifade eden açık bir mesaj vermektedir (Бостанланы, 1962: 11):

Bizni askerni karıvuna

Siññar asker teñ bolmaz

Curtha öşün salğan har cav

Uvalmay bir da kalmaz

Umut etmesin kanlı cav

Bizden eli cer almaz

K1z1l askerni katına

Çırtda cuvuk kelalmaz.
Bizim ordunun gücüne

Hiçbir ordu denk olamaz

Vatana saldıran her düşman

Paramparça olmadan kalmaz

Ümit etmesin kanlı düşman

Bizden bir karış toprak alamaz

Kızıl Ordunun yakınına

Hiçbir şekilde yaklaşamaz. 
Alman ve İtalyanlardan müteşekkil "faşist" ordusunun Sovyet topraklarına saldırma ihtimaline karşı bir Kızıl Ordu mensubu olarak her daim hazır ve tetikte olduğunu bildiren bir diğer şair de Muhammet Orus’tur (1916-1942). Bu şair de diğerleri gibi kendi arzusuyla Kızıl Orduya katılmış ve cephede Almanlara karşı savaşırken genç yaşta hayatını kaybetmiştir. Şairin, Almanların Sovyetlere taaruzu arifesinde kaleme aldığı "Toru Atım” (Doru Atım) ve "Kurç Kılıçım” (Çelik Kılıcım) adlı şiirleri meşhurdur. Şair bu iki eserinde; Kızıl Ordu askerlerinin Sovyet kolhozlarında yetiştirilen iyi cins "doru atlar"ın üzerinde ve bellerinde keskin bilenmiş "çelik kılıçlarıyla" düşman taarruzuna karşı hazır ve nazır olduklarını ifade etmektedir (Акбаев vd., 1965: 249):

\begin{tabular}{|c|c|}
\hline Kazavatha biz har minutda hazırbız & Savaşa biz her dakika hazırız \\
\hline Kurç kılıçlarıbıznı citi bileb & Çelik kılıçlarımızı keskin bileyip \\
\hline Faşist itle bizni kanlı cavlarıbız & Faşist itler bizim kanlı düşmanlarımız \\
\hline Atlarığızğa minigiz caşla deb & Atlarınıza binin gençler diye \\
\hline Komandirle bizge komanda bergenley & Komutanlar bize emir verdiğinde \\
\hline Sekirib kobub men katı uruşha tebrerme & Siçrayıp kalkarak ben savaşa giderim \\
\hline Men ata curtnu aslan köllü tavkel cigiti & Ben, ata yurdun aslan yürekli, cesur yiğidi \\
\hline Bir curtnu da tar özeni, karañı çegeti & Yurdun bir dar vadisi, karanlık ormanı dahi \\
\hline Bizden kutharmaz faşist Gitlerni kalak itin & Bizden kurtaramaz faşist Hitler' in uyuz itini \\
\hline Murdar Mussolinini ciyirgenilgen egetin. & Katil Mussolini’nin tiksindiren uşağını. \\
\hline
\end{tabular}

4. Almanların Sovyetlere Saldırması: "Büyük Vatan Savaşı" veya "Kutsal Savaş"

Almanlar 22 Haziran 1941 tarihinde ani ve hızlı bir şekilde Sovyet sınırlarını geçerek “yenilmez" Kızıl Ordu birliklikleri perişan ederek kısa süre içerisinde Moskova kapılarına dayanmışlardır. Gizli saldırmazlık anlaşmasına binaen Almanlardan böyle bir saldırı beklemeyen J. Stalin başlangıçta sinir krizlerine girmişse de kısa bir süre sonra toparlanarak bir dizi önlemler almaya koyulmuştur. J. Stalin ilk olarak bütün Sovyet halkına hitaben yaptı̆̆ı: "Yoldaşlar, yurttaşlar, kardeşlerim... Vatanımız ciddi bir tehlike altındadır...” şeklinde başlayıp, “Tüm gücümüzle desteğimiz kahraman Kızıl Ordu için! Halkımızın tüm gücünü düşmanın ezilmesine seferber edelim! Zafer için ileri!” şeklinde tamamladığı meşhur 3 Temmuz 1941 tarihli konuşmasıyla (Güvenir-Parlak, 2018), "Büyük Vatan Savaşı" şeklinde adlandırdığı "Kutsal Savaş"1 ilan ederek, bütün Sovyet halkını düşmana karşı vatanı savunmak için seferberliğe çağırmıştır. Yukarıda da belirtildiği üzere İkinci Dünya Savaşı, günümüz Rusya Federasyonunda ve eski SSCB ülkelerinde "Büyük Vatan Savaşı" (veya Büyük Vatanseverlik Savaşı) şeklinde adlandirılmakta ve daha ziyade 22 Haziran 1941 ile 9 Mayıs 1945 tarihleri arasında cereyan eden, eski SSCB'nin Nazi Alman ordularına karşı topraklarını savunduğu savaşları kapsamaktadır (Can, 2012: 43). 


\section{Adilhan ADİLOĞLU, "Sovyet Propagandası Çerçevesinde İkinci Dünya Savaşı'nın Karaçay-Malkar Edebiyatındaki Yansımaları”, Mavi Attas, 7(1)/2019: 16-51.}

J. Stalin'in direktifleriyle, Sovyetler Birliği hâkimiyetindeki milletlerin maddî ve manevî desteğini almak için baskıcı politikalar bir kenara bırakılarak, basın ve edebiyat sahası yoluyla yoğun bir şekilde propaganda faaliyetleri başlatılmıştır. Bu sebeple Sovyet rejimi taraftarı şair ve yazarların yanı sıra savaş öncesinde Stalin tarafından susturulan şair ve yazarlar bile vatan toprakları tehlike altında gerekçesiyle göreve çağrılmışlardır (Türker, 2002: 332).

Orta dereceli okullarda bile sözde "sosyalist hümanizm" fikrinin temellerini oluşturan ilkelerden birinin de "vatanı korumak" olduğu, bu sebeple vatan topraklarının düşman eline geçmesini önlemek için bütün Sovyet vatanseverleri gibi her bir öğrencinin gerekirse cepheye giderek düşmana karşı savaşması gerektiği propaganda edilmiştir (Къазалыланы, 1982: 42).

Müteakiben bütün ülke çapında ve yerel düzeyde basın ve matbuat faaliyetlerinde müthiş bir gelişme yaşanmıştır. Başta "Pravda" (Gerçek) ve "İzvestiya" (Haber) olmak üzere Sovyetler çapında yayın yapan büyük gazetelerin tirajı inanılmaz bir şekide arttırılmış, pek çok yeni gazete ve dergi yayınlanmaya başlamıştır. 1928 yılında Sovyetler genelinde 9.4 milyon tirajla 1.197 adet gazete yayınlanırken, bu sayı savaşın başlamasından sonra 8.806 adet gazeteye ve 38.4 milyon tiraja ulaşmıştır. Yine bu dönemde Karaçay'da yayınlanan ve yaklaşık 3 bin tirajı olan "Kızıl Karaçay” gazetesinin baskısı 9 bine çıkarılmıştır (Магулаева, 2010: 114-115).

Savaşın ilk günlerinde Pravda ve İzvestiya gazetelerinde Almanların taarruzu karşısında Sovyet ordusunun büyük kayıplar vererek geri çekilmesi gizlenmiş, daha çok cephede savaşan askerlerin erzak gereksinimi sağlamak için tarımsal faaliyetlerin arttırılması üzerine yazılan haberler yer almıştır (Аванесян, 2015: 49). Çünkü Kızıl Ordunun vaziyeti, öyle savaş öncesinde kaleme alınan şiirlerde yansıtıldığı gibi "yenilmez" değil, bilâkis oldukça berbat bir haldedir. Disiplinsizlik, askerî teçhizat ve lojistik unsurların yetersizliği, Kızıl Ordunun Almanlar karşısında gerilemesinin en büyük sebeplerinden birkaçıdır. Ancak bu gerilemenin belki de en önemli sebebi Kızıl Ordu askerlerindeki millî mensubiyet duygusunun eksik olmasıdır. Kızıl Ordu generalleri bile firsatını bulduklarında maiyetlerindeki askerlerle birlikte Almanların tarafına geçmekteydiler. Ancak bütün bu olumsuzlukların hiçbiri gazetelerde yansıtılmamış, tam tersine cepheden çeşitli haberler başlığ 1 altında Kızıl Ordunun Almanlara karşı kahramanca direnişleri anlatılmıştır (Sınar Uğurlu, 2009: 1754).

Karaçay'da bu dönemde "Kızıl Karaçay” adıyla yayınlanmaya başlayan gazetenin neredeyse bütün sayfaları savaşla ilgili konulara ayrılmıştır. Rus gazetelerinde olduğu 
gibi burada da, kolhoz ve sovhozlarda çalışan halkın cepheye erzak temini için daha çok çalışarak üretimi arttırmaları teşvik edilmekte, bazı kolhoz çalışanlarının fotoğrafları da konulmak suretiyle ne kadar çok patates yetiştirdikleri anlatılmaktadır. Aynı şekilde çok hayvan yetiştirip et ve süt üretimini arttıran kişilerden de övgüyle bahsedilmektedir. Böylelikle Kızıl Orduya lojistik destek için bütün halkın seferber olması gerektiği vurgulanmaktadır. Gazetenin bir sayfasında da "Frontdan Kelgen Pismola" (Cehpeden Gelen Mektuplar) başlığı altında, cephede savaşan askerlerden gelen sözde mektuplar aracılığıyla Kızıl Ordu askerlerinin cephede gösterdikleri kahramanlıklar anlatılmaktadır. Cepheden gelen mektuplara göre hali hazırda Sovyet ordusu biraz akamete uğramış olsa da, Almanların er ya da geç yenileceği, Kızıl Ordunun nihai zafere ulaşacağı bildirilmektedir (Блимголаны-Лайпанланы, 1975: 170).

Edebiyat sahasına gelince; savaş arifesinde bilhassa şiirde işlenen "düşmanı korkutma ve caydırma" temaları, savaş başladıktan sonra "vatan savunması" ve "seferberlik" temalarına kaymıştır. Bu dönemde; M. Şolohov, A. Tolstoy, A. Tvardovski, K. Simonov, M. İsakovski, N. Tihonov, İ. Ehrenburg, V. Lebedev-Kumaç gibi meşhur Sovyet şair ve yazarları bizzat savaşa katılarak eserlerinde bir taraftan Sovyet ordusunun cepdede düşmana karşı gösterdikleri kahramanlıkları coşkulu bir şekilde yansıtırlarken, bir taraftan da bütün Sovyet halkını vatan savunması için düşmanla mücadele etmeye ve seferberliğe çağırmaktadırlar (Къараланы-Борлакъланы, 1984: 48).

Karaçay-Malkar şairleri de aynı şekilde, kimisi orduya yazılarak bizzat cephede savaşmak suretiyle; kimisi de cephe gerisinde ama kalemlerini bir silah gibi kullanarak suretiyle düşmana karşı vatanı savunmak için canlarını feda etmeye hazır olduklarını ifade etmektedirler. Bu şairlerinin pek çoğu yukarıda isimleri sayılan meşhur Sovyet şairlerini ve onların eserlerini model almışlardır (Маммеев, 1978: 122).

İsa Karaköt, Davut Baykul, Tohtar Borlak, Hasan Bostan, Muhammet Orus, Salih Hoçu ve daha pek çok genç Karaçay-Malkar şairi Kızıl Orduya yazılarak savaşa katılmışlar ve cephede Almanlara karşı Sovyet ordusu saflarında savaşırken hayatlarını kaybetmişlerdir. "Birinci Devre" adını verebileceğimiz yukarıda isimleri sayılan bu şairlerin içerisinde ortaya koyduğu eserleriyle en dikkat çekeni Davut Baykul'dur. Savaş arifesinde bir yandan köy okullarında öğretmenlik yaparken, bir yandan da gazetecilik işini sürdüren Davut Baykul, Sovyetler Birliğinin İkinci Dünya Savaşı'na savaşına dâhil olması üzerine hemen orduya yazılarak savaşa katılmış; savaş sırasında bir yandan Sovyet ordusu namına askerî gazetecilik işini sürdürürken, bir yandan da şiir yazmayı da ihmal etmemiş, savaşla ilgili pek çok şiir kaleme almıştır. Meselâ, 1941 yılında propaganda 
maksadıyla basılan “Ata Curt Üçün Alga: Karaçay Poetleni Cırları” (Vatan İçin İleri: Karaçay Şairlerin Şiirleri) adlı kitapta yer alan şiirlerin yarıdan fazlası Davut Baykul'a aittir. Yine "İspan Kızçık” (İspanyol Kız Çocuğu), "Ata Curt Üçün Alğa” (Vatan İçin İleri), "Ur Cavnu Cerden, Suvdan, Kökden” (Yok Et Düşmanı Yerden, Denizden, Gökten), "Hasannı Tulparlarına" (Hasan Gölü Yiğitlerine), "Prizıvnikni Cırı" (Askerin Türküsü), "Ata Curtuñ Senden Anı İzleydi” (Ata Yurdun Senden Bunu İstiyor), "Cavnu Cer Tübüne Suğarbız" (Düşmanı Yerin Dibine Gömeriz), "Cutulur Cerge" (Yutulur Yerin Altına), "Kazavat Cır” (Savaş Türküsü), "Kazavatçı Süygen Kızına” (Savaşçıdan Sevdiği Kıza), "Kız Süygen Caşına” (Kızdan Sevdiği Delikanlıya), Üç Öhtemge” (Üç Kahramana), "Öhtemleni Ölümleri” (Kahramanların Ölümü), vb. başlıklı eserleri savaşla ilgili şiirlerdir. Bu sebeple Davut Baykul'u bir “Savaş Şairi” şeklinde adlandırmak çok da yanlış bir tabir olmayacaktır. Davut Baykul savaşla ilgili kaleme aldığı "Ata Curt Üçün Alğa" (Vatan İçin İleri) adlı eserinde bütün halkın düşmana karşı birleşmesini, küçük büyük, genç yaşlı demeden herkesin eline silah alarak cepheye koşmasını, cephe gerisindekilerin de ellerinde ne var ne yok bütün varlıklarını cepheye göndermelerini, gerektiğinde canlarını fedâ etmelerini istemektedir (Тохчуков, 1941: 5):

Birleş har barin kalmay artha

Ulluğa, gitçege, kartha deri al savutnu

Kisha et ala tuthan umutnu

Sal frontha, kızğanma malıñ

Kerek bolsa ber curtuñ üçün canıñı!
Birleşin hepiniz, durmayın geri

Büyük, küçük, ihtiyar demeden alın silahı

Kesin onların umutlarını

Gönder cepheye, k1skanma malını

Gerekirse ver yurdun için canını!

Yine aynı şairin "Prizıvnikni Cırı”" (Askerin Türküsü) başlıklı şiirinde, şair vatan topraklarına saldıran “domuz suratlı" Almanların paramparça edileceğini oldukça öfkeli bir şekilde ifade etmektedir (Байкъулланы, 1959: 13):

Çabhanlanı uvatırbız barısın

Ekinçide alnı beri burmazça

Bizni Sovyet baçhabıznı içine

Ala toññuz hamhotların urmazça.
Saldıranları parçalarız hepsini

Tekrar bu tarafa yönelemesinler

Bizim Sovyet bahçemizin içinde

Domuz suratlarını gösteremesinler.

Balkar şairleri; Safar Makit'in "Borçluma Curtuma" (Borçluyum Yurduma), “Tıñıla” (Dinle), "Rodinam” (Vatanım), Said Şahmurza'nın “Boluş Kralıña” (Yardım Et Devletine), Bert Gurtu'nun “Biz Hazırbız” (Biz Hazırız) başlıklı şiirlerinde, bütün Sovyet halklarının düşmana karşı vatan savunması için seferberlik çağrısı söz konusudur. Safar Makitov'un "Borçluma Curtuma” (Borçluyum Yurduma) adlı eserinde vatanın düşman işgalinden kurtarılması için gece gündüz demeden çalışılması gerektiği vurgulanmaktadır (Макитов, 1958: 5; Урусбиева, 1978: 105): 


\section{Adilhan ADİLOĞLU, “Sovyet Propagandası Çerçevesinde İkinci Dünya Savaşı’nın Karaçay-Malkar Edebiyatındaki Yansımaları”, Mavi Atlas, 7(1)/2019: 16-51.}

Borçluma men künümde, keçemde Borçluma men işimde, küçümde Curtumu küçlerge, kurç eterge Curtumu cavların gunç eterge.
Borçluyum ben gündüzümde, gecemde Borçluyum ben işimde, gücümde Yurdumu güçlendirmeye, çelikleştirmeye Yurdumun düşmanlarını yok etmeye.

Said Şahmurzayev de "Boluş Kralıña" (Yardım Et Devletine) başlıklı şiirinde benzer şekilde düşman kapıya dayanmadan önce bütün Sovyet halkının var gücüyle çalışarak savaşa hazır olması gerektiğini ifade etmektedir (Шахмурзаев, 1957: 68):

\section{Duşman sañña katılğınçı \\ Sen karıvuñ tohtağınçı \\ Boluş coldaş kralıña \\ Ömür seni bitdirginçi \\ Kartlık kesin bildirginçi \\ Küreş, işle, kralıña.}

\author{
Düşman sana gelmeden \\ Sen, gücün tükenmeden \\ Yardım et yoldaş devletine \\ Ömür seni bitirmeden \\ İhtiyarlık kendisini göstermeden \\ Uğraş, çalış, devletine.
}

Modern Karaçay-Malkar şiirinin kurucusu olarak kabul edilen ve Büyük Vatan Savaşı sırasında 80'li yaşlarda olan Kâzim Möçü'nün (1859-1945) bu dönemde kaleme aldığı savaş temalı "Biz Horlarbız (Biz Galip Geliriz), "Nemets Kirgendi” (Alman Girmiş), "Carlı Bala" (Zavallı Çocuk), "Bu Uruş Degeniñ Nedi” (Bu Savaş Dediğin Nedir) başlıklı şiirleri de mevcuttur. Şair "Biz Horlarbız (Biz Galip Geliriz) başlıklı eserinde Sovyet ordusunun er ya da geç bu savaşı kazanacağını söylemektedir (Мечиланы, 1989: 263):

Nemets bizge kacav boldu Çegibizge savut burdu Bizge bergen sözün buzdu

Asırı mardadan ozdu

Sovyet vlastnı alalmazla Bayrağın maltayalmazla Bir cumduruk bolurbuz Bizden küçlü bolalmazla.
Alman bize karşı oldu Hududumuza silah çevirdi Bize verdiği sözü bozdu Fazlasıyla haddini aştı

Sovyet ülkesini alamazlar Bayrağını çiğneyemezler Biz bir yumruk oluruz Bizden güçlü olmazlar.

"Büyük Vatan Savaşı”yla ilgili edebiyat sahasında çokça işlenen bir başka önemli tema ise askerlik çağına gelmiş Sovyet gençlerinin "kendi istekleriyle" ve "koşa koşa" Kızıl Orduya yazılmalarıdır. Sovyet yöneticilerinin direktifleriyle şairler özellikle bu konuyu eserlerinde sıkça dile getirmişlerdir. Aslında bunun sebebi de bu Sovyet gençlerinin askerlik görevinden "koşa koşa kaçmaları"dır. Zira savaşın yakıp kavurucu ateşiyle karşılaşan, başta Rusların kendileri olmak üzere, Sovyetlerin hâkimiyetindeki milletlere mensup pek çok genç cepheye gitmemek için asker kaçağı olmuştur. Sovyet ideolojisine yürekten inanmış az sayıdaki yerli komünist aydın ve diğer okumuşları 
saymazsak, Sovyet hâkimiyetindeki Rus olmayan milletlerin, özellikle de Türk halklarının bu "Büyük Vatan Savaşı"yla hemhâl olmaması da yadırganmamalıdır. Kırgız edebiyat eleştirmeni Salican Cigitov'un haklı olarak ifade ettiği üzere hiç kimse savaş meydanına öyle sevinçle ve atılarak gitmez. Ancak ve ancak yaşadığı ülkenin millî bilincini ve değerlerini tam anlamıyla özümsemiş insanlar vatanlarını savunmak için kendi istekleriyle savaşa giderler ve bu uğurda da canlarını seve seve feda edebilirler (Cigitov, 2004: 17). Fakat ortada temelleri kan ve gözyaşıyla inşa edilen "Sovyet Vatanı" ile bunun içerisinde oluşturulmaya çalışılan suni "Sovyet Ulusu” yalanından başka bir şey bulunmamaktadır.

Sovyet ordusuna yazılmayı ve cepheye gitmeyi reddeden asker kaçaklarının sayısı çok fazla artmaya başlayınca, Sovyet yetkilileri bir taraftan bu asker kaçaklarını yakaladıkları yerde kurşuna dizerek öldürürken, bir taraftan da Sovyet ordusunun asker sayısını arttırmanın yollarını arıyorlardı. Bu sebeple bir propaganda aracı olarak edebiyat sahası da devreye sokulmuş; Sovyet rejiminin kadrolu şairleri tarafından "kendi istekleriyle Sovyet ordusuna yazılarak cepheye koşan vatansever gençlerin” konu edildiği pek çok şiir kaleme alınmıştır. Bu tür şiirlerde dikkat çeken bir başka husus da, oğullarını askere uğurlayan "hüzünlü ve buruk anneler" yerine, "sevinçli ve mutlu anneler"in tasvir edilmesidir. Bunun en belirgin örneğini Hasan Bostan'ın "Kuvançlı Ana” (Mutlu Anne) başl1klı şiirinde görmek mümkündür. Eserde oğlunu askere gönderen bir annenin tarif edilmez bir mutluluk içerisinde (!) olduğu vurgulanmaktadır. Sözde bu "mutlu anne" oğluna Sovyet vatanı için hiç çekinmeden canını feda etmesi gerektiğini sıkıca öğ̈̈tlemektedir (Бостанланы, 1962: 15):

Alğın unuğub, endi kün tabhan Siylı ana curtun süyedi Nasıblı ana kuvançdan tolub Caşın askerge iyedi

Sen barasa curtuñu saklarğa Cokdu köb aytırım, köb derim Sen borçlusa ata curtuñu Cigitça saklarğa çeklerin

Curtha kol uzatsa kanlı cavuñ Küydürürse, açı urursa Ahırğa deri Sovyet curtuña Canıñ da ayamay turursa.
Önce kederliyken, şimdi mutlu olan Muhterem anne yurdunu seviyor Kutlu anne, içi mutlulukla dolan Oğlunu askere gönderiyor

Sen gidiyorsun yurdunu korumaya Yok diyecek fazla bir sözüm Sen borçlusun ata yurduna Hudutlarını yiğitçe korumaya

Vatana el uzatırsa kanlı düşman Yakarsin, acımadan vurursun Sonuna kadar Sovyet vatanını Canın1 esirgemeden korursun. 


\section{Adilhan ADİLOĞLU, “Sovyet Propagandası Çerçevesinde İkinci Dünya Savaşı'nın Karaçay-Malkar Edebiyatındaki Yansımaları”, Mavi Atlas, 7(1)/2019: 16-51.}

Savaş şairi Davut Baykul'un “Ata Curtuñ Senden Anı İzleydi” (Ata Yurdun Senden Bunu İstiyor) başlıklı şiirinde de aynı temayı görebiliriz. Bir anne ile oğlu arasında geçen diyaloglardan oluşan eserde, bir annenin vatan topraklarını düşmana karşı savunması için oğlunu askere gönderirken onu cesaretlendirmesi hikâye edilmektedir (Тохчуков, 1941: 10):

Ayhay balam, atlançı sen coluña

Ata curtuñ senden anı izleydi

Kılıçıñı sermeb alıb koluña

Şıbılaça, cavğa öhtem kir deydi

Tav kuşça çıç̧ı miyik köklege

Suvğa kirsen çabakça cüz teñizde

Serme cavnu, iyme bizni çeklege

Ata curtuñ ol borçnu saladı sizge.
Haydi yavrum, çık artık sen yoluna Ata yurdun senden bunu istiyor Kılıcını çekerek alıp koluna Yıldırım gibi düşmana saldır diyor

Kartal gibi çık sen yüksek göklere Suya girdiğinde balık gibi yüz denizde Karşı dur düşmana, geçirme serhaddimize Ata yurdun bu vazifeyi veriyor size.

Bu dönemde Sovyet şiirinin genelinde olmak üzere bir "mektup şiiri” cereyanı başlamıştır. Genellikle cephede düşmana karşı savaşan bir askerin annesine, kız kardeşine veya sevgilisine yazdığı mektup tarzında kaleme alınan bu tür eserlerin ilk örneklerini yine savaş döneminin önde gelen Rus şairlerinden Konstantin Simonov “Açık Mektup”, "Boş Sayfa" ve "Bekle Beni”" ile Dimitriy Bıkov "Kızın Mektubu” başlıklı şiirleriyle vermişlerdir. Müteakiben bu "mektup şiiri” Sovyet hâkimiyetindeki diğer Türk halklarının şiirinde olduğu gibi Karaçay-Malkar şiirine de sirayet etmekte gecikmemiştir. Davut Baykul'un "Kazavatçı Süygen Kızına” (Askerden Sevgilisine) ve "Kızdan Süygen Caşına" (Kızdan Sevgilisine), Tohtar Borlak'ın "Çekçi Zavurnu Zariyatha Pismosu" (Sınır Muhafızı Zavur'un Zariyat'a Mektubu), Canakayıt Zalihan'ın "Frontdan Pismo" (Cepheden Mektup), Kerim Otar'ın “Anama Pismo” (Anneme Mektup), Kaysin Kuliy’in "Egeçime Pismo" (Kız Kardeşime Mektup), Osman Hubiy’in "Kanlı Künde Kanatım” (Kanlı Günde Kanadım) ve daha pek çok Karaçay-Malkar şairi tarafından kaleme alınan bu tür eserlerde şairler genellikle cephede görev yapan askerlerin ağzından bir taraftan anneye, kız kardeşe veya sevgiliye duyulan özlem duygusunu ifade ederlerken, bir taraftan da kutsal vatan topraklarını düşmana karşı kanlarının son damlasına kadar koruyacakları mesajını vermektedirler (Маммеев, 1978: 132).

Davut Baykul'un "Kazavatçı Süygen Kızına” (Askerden Sevgilisine) başlıklı şiirinde bir askerin vatanı düşmana karşı korumak için cepheye giderken sevdiği kıza yazdığı mektupta, kesin bir ifadeyle vatanı işgal eden düşmanın yok edileceğine dair bir mesaj verilirken, vatan toprakları düşmandan temizlendikten sonra, iki sevgilinin düğünü ile zafer bayramının birlikte yapılacağı müjdelenmektedir (Тохчуков, 1941: 13): 
Ey meni karakaş süygenim

Kuturğan it kirgendi curtha

Sav kal endi sıylı nögerim

Men keteme kazavatha

İtleni kurutub ceterbiz

Basdırıb cerge sanların

Elibiz bla birge eterbiz

Eki kuvançnı toyların
Ey benim kara kaşlı yârim

Kudurmuş it girmiş vatana

Hoşça kal şimdi kıymetli yârenim

Ben gidiyorum savaşa

İtleri yok edip döneriz

Gömerek toprağa cesetlerini

Vatanımızla birlikte yaparız

İki sevincin düğün-bayramını.

Yine aynı şair tarafından kaleme alınan "Kız Süygen Caşına” (Kızdan Sevgilisine) başlıklı şiirde yukarıdaki mektuba cevaben, şair bu sefer askerin sevgilisinin ağzından seslenerek, vatan aşkının beşerî aşktan çok daha üstün ve yüce bir duygu olduğu mesajını vermektedir. Bu yüzden de askerin sevgilisi, sevdiği gence bir an bile düşünmeden vatan toprakları için canını feda etmesini tembihlemektedir (Тохчуков, 1941: 14):

Tutdur beri kurçdan katı koluñu

Salamlaşı mine kirçi atıña

Ariuvla sen ömürlükge coluñu

Bir kanlı da kelmez kibik katıña

$\mathrm{Bu}$ künlede canın artha salğannı

Anasından içgen sütü haramdı

Ayamay tök keñ tüzlege kir kannı

Bizni sıylı collarıbız horlamdı.
Uzat tutayım çelikten sert elini

Vedalaşarak binmeye hazırlan atına

Temizle sen ebediyyen yolunu

Bir düşman dahi yaklaşmasın yanına

Bu günlerde canını esirgeyenin

Annesinden içtiği süt haramdır

Acımadan dök bozkırlara kirli kanı

Bizim yüce yolumuz zaferdir.

Tohtar Borlak'ın “Çekçi Zavurnu Zariyatha Pismosu” (Sınır Muhafızı Zavur'un Zariyat'a Mektubu) başlıklı şiirinde de benzer şekilde, Sovyet sınırında görev yapan Zavur adlı bir askerin sevdiği kıza yazdığı mektup vasıtasıyla, mukaddes vatanın canı pahasına korunması gerektiği vurgulanmaktadır (Борлакъланы, 1939: 10):

Men Sovyet curtumu saklayma, ariuvum Tulpar atımı belinde Halkımı kuvançı toladı, ariuvum Meni cüregimde, kölümde

Men köz gincimçe saklayma, ariuvum Siylı curtumu çeklerin Ata curtum cüregimdi, bavurumdu Men añña iymezme faşizmni itlerin.
Ben Sovyet yurdumu koruyorum, güzelim Tulpar atımın belinde Halkımın sevinci doluyor, güzelim Benim yüreğimde, gönlümde

Ben göz bebeğim gibi koruyorum, güzelim Mukaddes yurdumun sinırlarını Ata yurdum yüreğimdir, ciğerimdir Ben oraya geçirmem faşizmin itlerini.

Savaş sonrasında, bilhassa nesir alanında oldukça büyük şöhret kazanmış olan Osman Hubiy'in (1918-2000) savaş sırasında kaleme aldığı şiirleri de mevcuttur. Meselâ bunlardan "Kanlı Künde Kanatım” (Kanlı Günde Kanadım) adlı şiiri meşhurdur. Osman 


\section{Adilhan ADİLOĞLU, "Sovyet Propagandası Çerçevesinde İkinci Dünya Savaşı’nın Karaçay-Malkar Edebiyatındaki Yansımaları”, Mavi Atlas, 7(1)/2019: 16-51.}

Hubiy bu şiirini, Rusların meşhur "Katyuşa" adlı şarkısına nazire olarak yazmıştır. Temeli bir halk türküsüne dayansa da savaş döneminde Mihail İsakovskiy (1900-1973) tarafından yeniden düzenlenerek kaleme alınan Katyuşa şiiri, bilâhare bestelenmek suretiyle bir şarkı haline getirilmiştir. Müteakiben bu şarkı bütün Sovyetler çapında çok sevilerek yaygınlaşmış ve adeta Kızıl Ordunun marşı haline gelmiştir. Osman Hubiy de "Kanlı Künde Kanatım” (Kanlı Günde Kanadım) adlı şiirinin mısralarını, Katyuşa şarkısının makamına uygun şekilde düzenlemiştir (Къагъыйланы, 1975: 128).

Kızıl Orduda askerlik görevini yapan bir Rus gencine âşık olan Katyuşa adlı küçük bir kızın hikâyesinde olduğu gibi, Osman Hubiy'in eserinde de aynı şekilde Kızıl Orduda askerlik yapan bir Karaçay gencine Ayşat adında küçük bir kızın aşkı söz konusudur. Ancak Katyuşa adlı eserde olayları hikâye eden 3. şahıs iken, Osman Hubiy'in şiirinde olaylar Ayşat'ın âşık olduğu askerin ağzından dile getirilmektedir. Yani eser vatan toprakları için sınırda görev yapan bir askerin Ayşat adlı küçük kıza yazdığı bir mektup mahiyetindedir. Ancak eserin sonunda Ayşat'ın bir seslenişi vardır ki, kendisi eğer âş1k olduğu genç savaşta ölürse onun intikamını almaya yemin etmektedir (Хубийланы, 1963: 58):

Korkma Ayşatçık, cavğa
Cav bolurma, kamamam
Ata curtnu saklavda
Caşavumu ayamam
Cav kutulmaz Ayşatım
Bir tırnaknı kanatıp
Bolur seni nür atıñ
Kanlı künde kanatım
Cüzgen ok tiyse kelib
Cerge avdursa meni
Bavurum bla sürkelib
Koruvlarma çekleni.

Korkma Ayşatçık, cavğa

Cav bolurma, kamamam

Ata curtnu saklavda

Cav kutulmaz Ayşatım

Bir tırnaknı kanatıp

Bolur seni nür atıñ

Cüzgen ok tiyse kelib

Cerge avdursa meni

Koruvlarma çekleni.

\author{
Korkma Ayşatcık, düşmana \\ Düşman olurum, geri durmam \\ Ata yurdumu korumakta \\ Hayatımı sakınmam \\ Düşman kurtulamaz Ayşatım \\ Bir tırnağı dahi kanatırsa \\ Olur senin nur adin \\ Kanlı günde kanadım \\ Kurşun girse gelip \\ Yere düşürse beni \\ Göğsümle sürünüp \\ Korurum hudutlar1.
}

Sovyet rejiminin kuruluş yıllarında yetişen Davut Baykul, Tohtar Borlak ve Hasan Bostan'a göre edebiyat sahasında çok daha meşhur olan Karaçay şairleri İsa Karaköt ile Azret Örten'den "Büyük Vatan Savaşı" sırasında pek bir ses çıkmadığı dikkat çekmektedir. Savaşın başlamasından önce eserlerinde Bolşevik ihtilâli, Sosyalizm, Sovyet rejimi, Sovyet hayatı, Komünist Parti, Lenin, vb. gibi konuları bolca işleyen İsa Karaköt (1900-1942) Sovyet reijiminin yetiştirdiği en önemli bayraktar şairlerden biridir. Bilahare 1924 yılında Moskova'da yayımlanan "Caññ Şigirle” (Yeni Şiirler) adlı şiir kitabının Karaçay-Malkar Türkçesiyle yayımlanmış Sovyet temalı ilk şiir kitabı olması 
sebebiyle kendisi de ilk Karaçay Sovyet Şairi olma unvanını kazanmıştır. İsa Karaköt, Almanların Sovyetler Birliğine saldırması üzerine orduya yazılarak cepheye giden ilk Karaçay şairidir. Maalesef kendisi cephedeki ilk günlerinde sıcak çatışmaya girmesi sebebiyle savaşta hayatını kaybetmiştir. Bu sebeple Büyük Vatan Savaşı ile ilgili eserler vermeye ömrü yetmemiştir. Bununla birlikte savaşının başladığı ilk günlerde birkaç dörtlük kaleme aldığı da rivayet edilmektedir. İsa Karaköt'e ait olduğu ileri sürülen bir dörtlükte şair henüz Sovyetler Birliğine saldırmamış olan Almanya'ya karşı tedbirli olmayı, hatta düşmanı kendi sahasında yok etmeyi tavsiye ederek, sosyalist devrimin bayrağını Avrupa'ya taşımayı arzu etmektedir (Къасайланы, 1974: 35):

Faşist cıyın keledi caydak atın üsdürüb Faşist topluluğu geliyor çıplak atıyla saldırıp Biz allına çığayık örten bolub küydürüb Biz önlerine çıkalım ateş olup, kavurup Kişenleyik, buvayık, curtubuzdan tiyayık Zincirleyelim, boğalım, yurdumuzdan men edelim İnkıylabnı bayrağın Evropada kurayık. Devrimin bayrağını Avrupa'da kuralım.

İkinci Dünya Savaşı'nın ilerleyen günlerinde, nihayet Almanların Sovyetler Birliğine saldırmasıyla birlikte orduya yazılan İsa Karaköt kaleme aldığı bir başka dörtlüğünde oldukça öfkelidir ve Sovyet ordusunun Almanların sonunu getireceğinden emindir. Hatta kızıl bayrağı Berlin'de dalgalandırmaya oldukça kararlıdır (Къасайланы, 1974: 37):

Kaytmazbız biz ızıbızğa

Faşistleni artın etmeyin

Kızıl bayraknı Berlinde çançıb

Muratıbızğa cetmeyin.
Dönmeyiz biz geriye

Faşistlerin sonunu getirmeden

Kızıl bayrağı Berlin'de dikerek

Maksadımıza erişmeden.

Sovyet rejiminin en ateşli savunucularından olan bir başka Karaçay şairi olan Azret Örten (1907-1955) ise bilhassa komünizmi öven coşkulu şiirleriyle ön plana çıkarak döneminin en meşhur şairi olmuştur. Buna rağmen Sovyet yetkilileri tarafından 1937 yılında tutuklanarak hapse atılmıştır. Azret Örten uzun yıllar boyunca sürgünde hapis hayatı yaşadıktan sonra 1955 yılında serbest bırakılmıştır. Yani kendisi Büyük Vatan Savaşı sırasında sürgünde hapis hayatı yaşamıştır. Bu sebeple de kendisinin edebî faaliyetlerde bulunması mümkün olmamıştır. Müteakiben şair memleketine dönerken, hapiste iken sağlı̆̆ bozulduğundan dolayı, yolculuk sırasında hayatını kaybetmiştir (Ёртенланы, 1959: 9).

\section{Cehpe Gerisi: Lojistik Destek}

Savaş zamanında, sıcak çarpışmaya giren askerlerin yanı sıra; cephe gerisinde silah yapımı, yiyecek ve giyecek üretimi gibi lojistik destek faaliyetleri, hem maddî, hem 
de manevî bakımdan savaşın seyrini değiştiren çok önemli bir unsurdur. Bu sebeple savaş zamanı edebiyat sahasında "çalışkan işçi ve köylüler" de ihmal edilmemiştir. Pek çok şair işçileri ve köylüleri cepheye lojistik destek sağlamak için daha çok çalışmaya teşvik eden tarzda eserler vermiştir.

Halimat Bayramuk'un "Sen Frontha Boluşamısa" (Sen Cepheye Yardım Ediyor musun) başlıklı şiirinde; asker olsun, sivil olsun, her bir Sovyet ferdinin vatanına ne şekilde yardımcı olduğu, nasıl destek verdiği sorgulanmaktadır. Şair eserinde bilhassa kadınları bu zor günlerde dik durmaya ve mücadele etmeye çağırmaktadır. Savaş zamanında kim nerede ne işle meşgul ise de bu meşguliyetin amacı sadece vatan savunması için olmalıdır. Meselâ tarlada, bahçede çalışan kadınlar, gece gündüz demeden çalışarak, cehpede savaşan askerlerin erzağını temin etmeli, gerektiğinde de ellerine silah alıp düşmanla savaşmalıdır. Yani bütün bir Sovyet halkı seferberlik içerisinde olmalıdır. Vatan savunmasında geride durmak ya da hiçbir şekilde katkıda bulunmamak en büyük utançtır. Bu utançla lekelenmemek için de düşmana karşı mücadele içerisinde yer almak gerekir (Къараланы-Борлакъланы, 1987: 102):

Bütev halk költürülgen zamanda

Curtnu sıyın saklar üçün savutlanıb

Kob sen da, artha, bedişli, turma da

Körgüz kişilikni cavdan kan alıb.
Bütün halk ayaklandığı zamanda Yurdun şerefini korumak için silahlanarak

Kalk sen de, utanç içinde geri durma Göster yiğitliğini düşmandan intikam alarak.

Yeri gelmişken Halimat Bayramuk'un "Büyük Vatan Savaşı" ile ilgili diğer eserlerinden de biraz bahsetmek gerekir. Bu dönemde edebiyat sahasına henüz yeni girmeye başlayan Halimat Bayramuk'un ilk şiirleri savaş dönemine denk gelmesi sebebiyle tabiatıyla o dönemin şartlarıyla kaleme alınmıştır. Şairin sırasıyla bu temayla ilgili olarak "Cukla Koynumda" (Uyu Kucağımda), "Frontda Keçe” (Cehpede Gece), “Tüzlük İşdi Horlarık” (Doğruluk Galip Gelecek), "Ant” (Yemin), "Frontdağı Teñime” (Cephedeki Arkadaşıma) başlıklı şiirleri vardır. Şairin "Tüzlük İşdi Horlarık” (Doğruluk Galip Gelecek) başlıklı şiirinde, dürüst ve haklı olan tarafın er ya da geç savaştan galip çıkacağı vurgulanmaktadır. Elbette burada haklı olan taraf Sovyetler Birliği'dir ve Almanları korkunç bir ölüm beklemektedir (Тохчуков, 1941: 22):

Teññiz kobhança kobhandı curtubuz Bu terslikge bolmasın deb bir tözüm Bizni eltedi partiyabız, devübüz Endi kelir faşistlege açı ölüm

Sovyet halknı bu tolkunun kim tıyar Kaysı cavdu andan horlam sıyırlık
Denizin taşması gibi kabardı yurdumuz $\mathrm{Bu}$ haksızlığa karşı olmasın diye bir sabır Bizi götürüyor partimiz, kudretimiz Şimdi gelir faşistlere korkunç ölüm

Sovyet halkının bu taşkınına kim mani olur Hangi düşmandır ondan zaferi alacak 


\section{Adilhan ADİLOĞLU, “Sovyet Propagandası Çerçevesinde İkinci Dünya Savaşı'nın Karaçay-Malkar Edebiyatındaki Yansımaları”, Mavi Atlas, 7(1)/2019: 16-51.}

Tüzlüknü işi har ömürde da horlar

Tüzlüknü işidi taymazdan alğa barlık.
Doğruluk her devirde de galip gelir

Doğruluktur daima ileri gidecek.

Halimat Bayramuk'un yine bu temayla ilgili olarak "Ant” (Yemin) adlı şiirinde şair bizzat vatanı korumak için ölmeye yemin ettiğini gururla haykırmaktadır. Çünkü göğsünde Kızıl Yıldız nişanını taşımaktadır. Şaire göre bu yüce nişanı taşıyan her bir kişi gerektiğinde vatanı için ölüm ateşine girmek zorundadır. Şair de, Sovyet vatanının ve Stalin'in huzurunda, hiç korkmadan bu ölüm ateşine girmeye yemin etmektedir (Тохчуков, 1941: 33):

Cürek bügün başha türlü uradı Kolum bügün katı kıshandı şkoknu Kızıl culduz kökregimde canadı

Bügün antın etgenme Sovyet uruşçunu

Berilmeydi bu at bizge boşuna

Anı siyı mahdavludu, miyikdi

Anı alğan har uruşçu kerek bolsa

Curtu üçün ölüm otha kirlikdi

Ant eteme Sovyet kral men allıñda

Ant eteme Stalin atam sañña

Faşizmni ahır künün etginçi küreşirikme

Korkuv kelmez mañña.
Yürek bugün başka türlü çarpiyor

Kolum bugün sıkı tutuyor tüfeği

Kızıl yıldız göğsümde parlıyor

Bugün Sovyet askerinin ettim yeminini

Verilmiyor bu ad bize boşuna

Onun değeri şanlıdır, yücedir

Onu alan her asker gerektiğinde

Yurdu için ölüm ateşine girecektir

Yemin ediyorum Sovyet vatanım huzurunda

Yemin ediyorum Stalin atam sana

Faşizmin sonu gelinceye kadar uğraşacağım

Korku gelmez bana.

Bert Gurtu'nun “Savğala” (Hediyeler) başlıklı şiiri de yine bu maksatla kaleme alınmıştır. Şair eserinde temiz bir elbise, taze ve lezzetli bir yiyecek, hatta incik boncuk gibi küçük bir hediyenin bile cephede sıcak çatışmaya giren askerin gönlünü okşayacağını ve ona büyük moral olacağını, böylece kimlerin uğruna savaştığının bilincinde olarak düşman üzerine daha bir coşkuyla saldıracağını vurgulamaktadır (Гуртуев, 1958: 90):

Uruş crrğa küç beredi bir ızğa ejüv Alğa terk tebindiredi boluşluk sezüv Uruşçula köllenedile alğa barırğa Tuvğan curtha söz beredile horlav alırğa Duşmandan erkin eterge bizni cerleni Adamlanı, şaharlanı, har bir elleni.
Savaş türküsüne güç verir bir ağızdan eşlik etmek İleri yürütür daima geride destek olduğunu sezmek Askerler de cesaretleniyor hep ileri gitmeye Öz yurtlarına söz veriyorlar ulaşmak için zafere Düşmandan kurtarmak için bizim topraklarımızı İnsanlarımızı, şehirlerimizi, bütün köylerimizi.

Aynı şair "Uv Cılannı Ezerge" (Zehirli Yılanı Ezmek) adlı şiirinde ise savaş zamanında vatan savunmasından kaçan, bu zor günlerde canını malını esirgeyen kişileri bir zehirli yılana benzetmekte ve kim olsursa olsun böyle haysiyetsiz insanları aralarında barındırmayacaklarını ifade etmektedir (Гуртуев, 1958: 75): 
Kerek künde kanın-canın ayağan Korkub, kaçıb, sıysız caşav saylağan Kim bolsa da koratırbız aradan Kerek tüyüldü boluşluk aladan.
İhtiyaç olduğunda kanını, canını esirgeyen Korkup, kaçarak, haysiyetsiz hayatı seçen Kim olursa olsun, yok ederiz aramızdan Lâzım değil bize destek onlardan.

\section{Düşmanı İtibarsızlaştırma}

Almanlar işgal ettikleri Sovyet toprakları içerisindeki bazı bölgelerde yerli halkın kendileriyle işbirliği yapmalarını sağlamak maksadıyla onları kendi taraflarına çekmek için özel bir gayret sarfetmişlerdir. Neticede Almanların işgaliyle karşı karşıya kalan Sovyet halklarından kimisi baskıcı Sovyet rejiminden kurtulmak için, kimisi de Almanların zulmünden korktukları için onlarla işbirliği içerisine girmişlerdir. Bunun üzerine Sovyet yetkilileri işgal altındaki topraklarında Almanların birtakım vaatlerine kanarak onlarla işbirliği içerisine girme ihtimaline karşı vatandaşlarını Almanlardan soğutmak ve uzak tutmak maksadıyla çeşitli propaganda faaliyetlerine başlamışlar; radyo, gazete, broşür ve edebiyat kanalları aracılığıyla Alman askerlerini küçük düşürücü, aşağılayıcı ve hatta korkutucu şekillerde göstermek yoluyla Sovyet vatadaşları nezdinde gözden düşürmeye, itibarsızlaştırmaya çalışmışlardır.

1942 yılı Ağustos ayında Kuzey Kafkasya bölgesinin bir kısmını işgal eden Almanlar yaklaşık beş ay boyunca Karaçay-Malkar topraklarında kalmışlardır. Bu süre zarfinda Almanlar öteden beri Sovyet rejimine karşı olan çok küçük bir kesimin desteğini almaya muvaffak olmuşlardır. Ancak halkın büyük bir kısmı Almanlarla işbirliğine yanaşmamış, tam tersine partizan (sivil direniş) birlikleri kurmak suretiyle Almanlara karşı mücadele etmişlerdir. $\mathrm{Bu}$ arada yerli şairler de boş durmamış, birtakım vaatlerle halkı kendi yanlarına çekmelerini önlemek maksadıyla Almanları halkın gözünden düşürmek için pek çok şiir kaleme almışlardır. Meselâ Azret Buday’ın "Ata Curt Uruşha, Alğa" (Vatan Savaşına, İleri), Davut Baykul'un "Ur Cavnu Cerden, Suvdan, Kökden" (Yok Et Düşmanı Yerden, Denizden, Gökten), Kaysın Kuliy'in "Murdarnı Millığı" (Katilin Leşi), Abdülkerim Baykul'un "Colğa Aşık” (Yola Çıkmak İçin Acele Et), Bert Gurtu'nun "Uv Cılannı Ezerge” (Zehirli Yılanı Ezmek), “Zulmuçula” (Zalimler) başlıklı eserlerinde Almanları kötüleyici ve aşağılayıcı ifadelere yer verilmektedir (Толгуров, 1978: 35).

Almanlar Kuzey Kafkasya bölgesini işgal ettikleri sırada, Holam-Bızıngı bölgesinde Almanlara karşı silahlı direnişe geçen "partizan” adı verilen milislerin safinda çarpışan ve sonrasında Alman askerleri tarafından yakalanarak öldürülen Malkar şairi Azret Buday'ın (1915-1942) vatan savunması için halkı silahlı mücadeleye davet ettiği “Ata Curt Uruşha, Alğa" (Vatan Savaşına, İleri) başlıklı şiirinde Hitler korkunç, iğrenç 


\section{Adilhan ADİLOĞLU, “Sovyet Propagandası Çerçevesinde İkinci Dünya Savaşı'nın Karaçay-Malkar Edebiyatındaki Yansımaları”, Mavi Atlas, 7(1)/2019: 16-51.}

ve insan eti yiyen tabiatüstü bir canavar şeklinde tasvir edilmektedir (Будаев, 1976: 11, 81). Elbette buradaki maksat işgal altında kalan yerli halkın bir şekilde Almanların vaatlerine kanarak onlara itibar etmelerini önlemektir:

Çamlandırıb Sovyet halknı kesine

Ne tüşgendi uv c1lannı esine

Nek költürgendi ol başın bizge

Nek kirgendi bazınıb ceribizge

Ol nek boyaydı keñ cayakların kañña

Nek tatlıdı adam eti añña

Alğa! Ullu halkım alğa!

Bir da kalmay, ata curt uruşha!
Öfkelendirip Sovyet halkını kendisine Ne geldi bu zehirli yılanın aklına

Niçin çevirdi o başını bize

Niçin girdi cesaret edip bizim yurdumuza

O niçin boyadı geniş yanaklarını kana

Niçin tatlıdır insan eti ona

İleri! Yüce halkım ileri!

Geri durmadan, vatan savaşına!

Davut Baykul'un eski Karaçay-Malkar masallarındaki motiflerden de faydalanarak kaleme aldığı "Ur Cavnu Cerden, Suvdan, Kökden” (Yok Et Düşmanı Yerden, Denizden, Gökten) adlı şiirinde; ahlâksız, iğrenç ve vahşi bir mahlûk şeklinde tasvir edilen Hitler beş başlı canavara benzetilmektedir (Тохчуков, 1941: 3):
Adamğa koy, uşamağan kiyikge
Anı kanlı uyası ornalıbdı Berlinde
Değil insana, benzemiyor yabaniye
Har uyatnı unuthandı ol
Onun kanlı yuvası kurulu Berlin'de
Sav duniyaga kanlı işni tuthandı ol
Her bir hayâyı unutmuştur o
Bütün dünyaya kanlı işi tutmuştur o
Urmayın tohtağınçı cüregi
Çarpmayıp durana dek yüreği
Tar1 elek bolğunçu kökregi
Göğsü olana dek darı eleği
Ur anı cerden, suvdan, kökden
Yok et onu yerden, denizden, gökten
Kuthar halknı beş başlı saruvbekden.
Kurtar halkı beş başlı canavardan.

Kaysın Kuliy'in (1917-1985) "Murdarnı Mıllı̆̆ı” (Katilin Leşi) başlıklı denemesinde ise Alman askerleri ve Hitler'in "üstün 1rk" teorisi alaycı bir dille eleştirilmektedir. Şair eserinde bizzat şahit olduğu bir olaya binaen; savaşta ölen bir Alman askerinin cesedini hicvederek tasvir etmektedir: "Faşistin leşi yere sırt üstü serilmiş yatıyor. Kurşun göğsüne girmiş. Onun 'ari saçları' birbirine karışmış, dağılmış ve üzerine 'çamur' bulaşmış. Rus toprağına temas etmek istememiş olmalı ki, iki eli de göğsünün üzerinde, birbirine kavuşmuş halde duruyor.” (Маммеeв, 1978: 128).

Almanları ve Hitler'i aşağılayıcı ifadeler kullanmak suretiyle onları halk nezdinde itibarsızlaştırmak maksadıyla şiirler yazan bir diğer şair Abdülkerim Baykul'dur (19121988). Kendisi savaşa katılan ikinci devre şairlerden olup, aynı zamanda Davut Baykul'un da kardeşidir. Savaşa katılmadan önce uzun müddet Sovyet rejimini halka benimsetmek amacıyla profesyonel propagandist olarak çalışmıştır. İşinin gereği olarak 
da pek çok şiir yazmış ve yine pek çok şiir kitabı yayımlamıştır. Ancak bunların neredeyse tamamına yakını Sovyetik temalı ve propaganda amaçlı şiirlerdir. Böyle olmayan belki bir ya da iki şiiri vardır. Ağabeyi Davut Baykul'un savaş sırasında hayatını kaybetmesi üzerine bu sefer kendisi de orduya yazılarak savaşa katılmıştır. Cephede savaşırken ağır yaralanmış ve iki gözünü kaybetmiştir.

Abdülkerim Baykul'un savaşla ilgili kaleme aldığı "Colğa Âşık” (Yola Çıkmak İçin Acele Et), "Cavğa Ölüm” (Düşmana Ölüm), "Bandit Uya Çaçılır” (Eşkıya Yuvası Parçalanır), "Ezerbiz Cavnu” (Ezeriz Düşmanı), "Curt Çakıradı” (Vatan Çağırıyor), "Sav Kal” (Hoşça Kal) ve "Esimdedi” (Hatırımda) gibi daha pek çok şiiri vardır. Abdülkerim Baykul'un savaş temalı şiirlerinin tamamı, halkın zihninde ve duygu dünyasında sarsıntı yaratarak, düşmana karşı direnmeyi ve akabinde saldırmayı körükleyen ajitasyon şiirleridir. Meselâ "Colğa Âşık” (Yola Çıkmak İçin Acele Et) başlıklı şiirinde, Alman askerlerinin Sovyet topraklarına girdikten sonra sivil halka türlü türlü zulümler yaptıklarını, masum kadın ve çocukları katlettiklerini, geçtikleri yerlerde bulunan köyleri yakıp yıkarak yerle bir ettiklerini söyledikten sonra, halkı düşmana karşı silahlı mücadeleye çağırmakta, ayrıca Hitler'i de "kan içici”, "hunhar", "it", "zehirli yılan", "ahlâksız", "tiksindirici" ve "iğrenç" gibi aşağılayıcı sıfatlarla tasvir etmektedir (Байкъулланы, 1958: 12):

Kan içüvçü Gitler küçün iygendi Hauh karıvun horlanmazça körgendi Askerine faşist buyruk bergendi Eki ayğa tuluk etigiz degendi

Ma bilayd 1 it Gitlerni murat1 Uv c1lañña tüz uşağan suratı Adam kañña sıyınmağan uyatı Alçı tılpuvu ciyirgeññen kir atı.
Kan içici Hitler ordusunu göndermiş Eğreti askerlerini yenilmez sanıyor Askerlerine faşist emri vermiş İki ay içinde her yeri alın diyor

İşte böyle it Hitler'in maksadı Zehirli y1lana benzeyen surat1 İnsanlığa sığmayan ahlâksızlığı İlk nefeste tiksindiren iğrenç adı.

Bert Gurtu'nun "Zulmuçula” (Zalimler) adlı eserinde ise Alman askerleri insanların kanını içen korkunç yaratıklar şeklinde gösterilmektedir. Eserde ninesiyle birlikte yaşayan altı yaşındaki bir kız çocuğunu bileklerini keserek kanını içmek suretiyle öldüren üç Alman askerinin zalimlikleri hikâye edilmektedir (Гуртуев, 1958: 80):

Faşistleden uzun sanlı, sarı şinli ofitser Üy tübde kolan kiyizge kusadı Adam kanı içerikme keltir ber Deb teñlerin aşıkdırıb kısadı
Faşistlerden uzun boylu, sarışın subay Evin zeminindeki alacalı kilime kusuyor İnsan kanı içeceğim, getirin, verin Diye arkadaşlarını sürekli zorluyor 
Sabiyçikni tartıb, ceñçigin cırtıb

Bilekçigin sozdula, sermedile

Cılan urğan ulak kibik makırtıb

Adam eşitmegen azabnı berdile

Innaka da karab köre turğanlay

Sabiyçikni kan tamırın kesdile

Çömüçnü issi kandan tolturğanlay

Adam kannı közüv közüv içdile.
Çocuğu hırpalayıp, kolunu yırtarak

Bileğini hoyratça çektiler, incittiler

Yılan sokmuş oğlak gibi bağırttılar

İnsanın görmediği azabı çektirdiler

Ninesinin de gözleri önünde

Çocuğun kan damarını kestiler

Çömçeyi sıcak kanla doldurup

İnsan kanını sıra sıra içtiler.

\section{Kahraman Sovyet Kadını}

Sovyetler Birliğinin muhtelif bölgelerinden yaklaşık 200 bin kadın Kızıl Orduya alınarak cepheye gönderilmiş ve bu kadın askerlerin en az yüzde 70 kadarı sıcak çatışmaya girmiştir. Almanların işgal ettiği, Sovyettler Birliğinin iç kısımlarında direniş hareketlerine de en az 800 bin kadının katıldığg tahmin edilmektedir. Dolayısıyla, Büyük Vatan Savaşı sırasında verilen edebî eserlerin en önemli temalarından biri de "Kahraman Sovyet Kadını" şeklinde karşımıza çıkmaktadır. Bu tür eserlerin hemen hepsinde savaş döneminde çok önemli görevler üstlenen ve savaşın seyrinde büyük rol oynayan, vatanı için canını feda eden "Sovyet kadını" idealize edilmektedir (Aleksiyeviç, 2002: 12).

Sovyet-Rus edebiyatında "Kahraman Sovyet Kadını" temasının en bilinen sembol ismi “Zoya Kosmodemyanskaya” (1923-1941) adında genç bir Rus kadınıdır. Almanların Moskova’yı işgal etmesi üzerine sivil halk "partizan” adı altında örgütlenerek Almanlara karşı direnişe geçmiştir. Bu örgütlerin birinde yer alan ve Almanlara epece bir zayiat verdiren Zoya Kosmodemyanskaya 1941 yılı Aralık ayında Almanlar tarafindan yakalanmış ve kendisi henüz 18 yaşında iken idam edilmiştir. Bu olay bütün Rusya'da halk nezdinde büyük bir infial yaratmış, buna paralel olarak da gerek basın yayın organlarına ve gerekse edebiyat sahasına büyük tesiri olmuştur. Konstantin Simonov, M.İ. Aliger, F.A. Vigdorova, V. Kovalevskiy, P. Huzangay gibi daha pek çok Sovyet şair ve yazarı Zoya Kosmodemyanskaya ile ilgili eserler vermişlerdir. Bu olayların yaşandığ 1 sırada başka bir cephede görev yapan Karaçaylı şair Davut Baykul da bu temayla ilgili olarak "Zoya" (1942) adlı uzunca bir şiir kaleme almıştır (Къараланы-Борлакъланы, 1984: 15). Bu arada Türk şairi Nazım Hikmet'in de "Memleketimden İnsan Manzaraları" adlı eserinde, 1945 yılında Bursa cezaevinde iken kaleme aldığı, Zoya Kosmodemyanskaya'ya ithafen bir bölüm yer almaktadır (Hikmet, 2008: 1408-1417).

Zoya Kosmodemyanskaya'nın başına gelen olayın bir benzeri de Karaçay'da yaşanmıştır. Almanlar Kuzey Kafkasya'yı işgal ederek Karaçay topraklarına girdikleri zaman burada dağınık halde bulunan Sovyet birlikleri ve yerli halktan oluşan milis 


\section{Adilhan ADİLOĞLU, “Sovyet Propagandası Çerçevesinde İkinci Dünya Savaşı'nın Karaçay-Malkar Edebiyatındaki Yansımaları”, Mavi Atlas, 7(1)/2019: 16-51.}

güçlerinin direnişiyle karşılaşmıştır. Bu milis güçleri arasında istihbarat görevini yürüten Zalihat Erikgen (1913-1942) adında genç bir Karaçaylı kadın Almanlar tarafından yakalanarak uzun bir süre boyunca hapishanede işkence altında tutulmuştur. Zalihat Erikgen nihayet arkadaşlarının da yardımıyla hapishaneden kaçmaya muvaffak olursa da kaçış yolunda Alman askerleri tarafından yakalanarak kurşuna dizilmiştir. Zoya Kosmodemyanskaya ile hemen hemen aynı şeyleri yaşayan Zalihat Erikgen bilâhare Karaçayda “Karaçay’ın Zoya Kosmodemyanskayası” şeklinde anılmıştır.

Zalihat Erikgen'in etrafinda cereyan eden bu olaylar elbette Karaçay-Malkar edebiyatına da yansımıştır. Bu konuyla ilgili olarak en önemli eser; Halimat Bayramuk tarafindan savaş yıllarında kaleme alınmakla birlikte ancak 1963 yılında yayımlanabilen "Zalihat" adlı "poema” (uzun şiir)'dir. Müstakil bir kitap şeklinde ve toplam 122 sayfadan oluşan bu eser: "Rahat Künle" (Rahat Günler), "Kara Künle" (Kara Günler), "Sermeşüv" (Çarpışma) ve "Türmede" (Hapiste) gibi başlıklardan mütevellit on üç bölümden oluşmaktadır. Eserde, Zalihat Erikgen'in şahsında vatan için canını feda eden kahraman Sovyet kadını idealize edilmektedir. Eserin sonunda da Zalihat Erikgen'in yiğit bir şekilde vatan için can verdiğini görüyoruz. Zalihat Erikgen'in Almanlar tarafından öldürülmesi karşısında tabiatın aldığı tutum da dikkate değerdir (Байрамукъланы, 1963: 108):

Maşinalanı tohtatdıla Nemçalıla

Çı̆̆ı̆̆ı deb hını hını kıçırdıla

Partizanla kürekleni oynatdila

Faşistleni ekevlenin soylandırdıla

Bılağa da avtomatla kuyuldula

Dev avazla köbge barmay tıyıldıla

Elek boldu butu, kolu Zalihatnı

Kara keçe közlerine avun atdı

Boz kayala açuvlanıb dünürdedile

Cavğa burub öşünlerin gürüldedile

Carıb atıb kelgen tañnı kök türsünü

Muthuz boldu tamğa tüşdü anı üsüne

Mingitavdan bu zorlukğa karab turub

Kelib kondu bu başlağa kara bulut

Altın kün da bügün cerni carıtmadı

Ariuv betin kanlı cavğa karatmadı.
Arabaları durdurdular Almanlar

Çıkın diye öfkeyle bağırdılar

Milisler kürekleri salladılar

Faşistlerin ikisini yere serdiler

Bunlara da makineli tüfekleri boşalttılar

Gür sesleri bir zaman sonra kesildiler

Delik deşik oldu bedeni Zalihat' in

Karanlık gece gözlerine perdeyi indirdi

Boz kayalıklar öfkeden titrediler Düşmana karşı dönüp gürlediler Ağarmaya başlayan günün mavi çehresi Soldu, hüzünlendi, leke düştü üstüne

Elbruz dağından bu zulmü seyreden Gelip kondu oraya kara bir bulut Altın güneş de o gün yeryüzünü aydınlatmadı Güzel yüzünü kanlı düşmana göstermedi.

Sovyet dönemi Karaçay-Malkar edebiyatında bilhassa hikâyeleriyle tanınan Salih Hoçu (1910-1942) da savaşa kendi isteğiyle katılan birinci devre yazarlardandır. Maalesef diğerleri gibi o da genç yaşında iken savaşta hayatını kaybetmiştir. Salih 
Hoçu'nun cephede iken kalame aldığı "Cigitle” (Yiğitler)” adlı hikâyesinde, Almanların taarruzu üzerine geri çekilmek zorunda kalan bir Sovyet asker bölüğünde hemşire olarak görev yapan Lüba adlı bir kadın askerin kahramanlığı anlatılmaktadır. Yukarıda bahsedilen Zoya Kosmodemyanskaya ile Zalihat Erikgen'in hikâyesine benzer bir şekilde Almanların eline esir düşen Lüba adlı kadın asker, Almanların türlü işkencelerine rağmen onlara boyun eğmemiş ve vatanı için canını fedâ etmiştir (Хочуев, 1986, 184-194).

\section{Savaşın Gerçekliği}

İkinci Dünya Savaşı'nın başladığı yıllarda öğretmenlik mesleğiyle meşgul olan ve aynı zamanda edebiyat sahasına yeni girmeye başlayan Kaysın Kuliy (1917-1985) de kendi isteğiyle orduya yazılarak savaşa katılan şairlerdendir. Cephede savaşırken ağır yaralanmış, Moskova'da tedavi gördükten sonra, askerlikten muaf tutulmasına rağmen, tekrar cepheye dönmüştür. Ancak cephede askerlik yapmak için beden sağlığ bakımından elverişsiz olduğu anlaşılınca kendisi "Sın Oteçestva" (Vatanın Oğlu) adlı askeri gazetede muhabir olarak görevlendirilmiştir. Şair bu gazetede görev yaptığı sırada bir taraftan cephede cereyan eden gelişmeleri haber şeklinde yazıp yayınlarken, bir taraftan da savaşa dair şiirler, hikâyeler ve denemeler kaleme almıştır. Şairin savaşla ilgili yazdığı eserler arasında "Uruş" (Savaş), "Şinel Kiygen Kız" (Palto Giyen Kız), "Cır" (Türkü), "Murdarnı Mıılığı” (Katilin Leşi), "Ullu Cigitlik”, (Büyük Yiğitlik), "Sermeşni Allında" (Savaş Arifesinde), "Frontda Caz" (Cephede Bahar), "Uruşnu Suratları" (Savaşın Fotoğrafları), "Üyge Kaytmazlıklanı Üsünden” (Eve Dönmeyecek Olanlar Hakkında) ve "Kobuz" (Armonika) başlıklı şiirlerini saymak mümkündür.

Kaysın Kuliyev'in de bazı şiirlerinde dönemin havasına uygun olarak Sovyet askerlerini öven, hatta onları masal kahramanlarından bile üstün gösteren mısralara rastlamak mümkündür. Ancak bazı şiirlerinde de o dönemin basmakalıp ve sloganvari ifadelerinden sıyrılarak, savaşın gerçekliğini cesur bir şekilde gözler önüne sermeyi başarabilmiştir. Meselâ "Uruş" (Savaş) adlı eserinde savaşın kitaplarda anlatılandan çok daha zor ve çetin olduğunu, düşmanı yenmenin de öyle "kötü şairlerin" söylediklerinin aksine hiç de kolay olmadığını savaşın en sıcak günlerinde cesurca dile getirmiştir. Şairin bizzat kendisi cephede sıcak çatışmaya girmiş ve ağır yaralanmıştır. Bu sebeple savaşın gerçekliğini çok iyi bilmektedir. Ona göre savaş da, düşmanı yenmek de gerçekten çok zor bir iştir. Bu sebeple savaşın gerçekliği hakkında yalan söylemek de korkakların işidir (Кулиев, 1958: 152):

Duşmannı horlağan tınçdı degen Osal nazmuçula da boladıla
Düşmanı yenmek kolaydır diyen

Kötü şairler de olabilir 
Ala kişilikni añılamayın

Soldatlanı da ters suratlaydıla

Caşavnu üsünden ötürük aythan

Ol işidi kölsüzleni, korkaklanı

Uruş degeniñ kıyın tavuşdu

Kıyındı uruşhan, horlağan duşmannı

Uruş kıyındı, alay a erkinlikni

Saklarbız kulluk ete kertilikge

Biz kökregibiz bla cabarbız

Seni duşman okladan kıralıbız.
Onlar yiğitlik nedir bilmeden

Askerleri farklı gösterebilir

Hayat üzerine yalan söylemek

Yüreksizlerin, korkakların işidir

Savaş dediğin zor ve çetindir

Zordur savaşmak, düşmanı yenmek

Savaş zordur, fakat özgürlüğü

Koruruz, görevimiz bizim hakikat için

Biz göğsümüzle dahi siper oluruz

Vatanım, seni düşmandan korumak için.

Büyük Vatan Savaşının bir başka cesur şairi de Kerim Otar'dır (1912-1974). Karaçay-Malkar edebiyatının en önemli temsilcilerinden biri olan Kerim Otar bilhassa modern Malkar şiirinin; Kâzim Möçü ve Kaysın Kuliy ile birlikte üç büyük şairinden biri olarak kabul edilmektedir. Şairin eserlerinde gerçekten de güçlü bir lirizm vardır. Millet sevgisi ve yurt özlemi temalı şiirleri oldukça coşkulu ve duygu yüklüdür. Kerim Otar, İkinci Dünya Savaşı sırasında, iki ağabeyinin de Kızıl Orduda asker olarak görev yapması sebebiyle, askerlik görevinden muaf tutulmuş olmasına rağmen, hiç tereddüt etmeden, kendi isteğiyle orduya yazılarak, şiddetli çarpışmaların cereyan ettiği cephelerde Almanlara karşı Sovyet ordusu saflarında savaşmıştır. Kerim Otar bu savaştan sağ çıkmayı başarabilmişse de, iki ağabeyini ve bir bacağını savaşta kaybetmiştir (Отарланы, 1997: 6).

Kerim Otar savaş temasıyla ilgili olarak en fazla eser veren şairlerden biridir. "Ant" (Yemin) ve "Azatlık Bayrağı" (Özgürlük Bayrağı) gibi Sovyet askerlerinin kahramanlığını öven, vatan savunması için halkı birlik olmaya ve seferberliğe çağıran propaganda türü şiirleri de vardır. Bununla birlikte savaşı bizzat yaşayıp acı bir şekilde tecrübe eden şairin savaş sırasında yaşanan felaketleri; yakılıp yıkılan köyleri, ölen masum insanları tüm gerçekliğiyle yansıtan eserleri de mevcuttur. Şairin savaş temasıyla ilgili şiirlerinin neredeyse tamamında "kan" kelimesi geçmektedir. Şair bununla şiirlerinde savaşın ne kadar "kanlı" olduğunu anlatmaya çalışmaktadır. "Kim Biledi?" (Kim Bilir?) başlıklı şiirinde savaşın her iki tarafında da pek çok canlar feda edilirken, geride kalan yetimlerin acıklı hallerine dikkat çekmekte, savaşın her iki tarafa da yıkım ve felâketten başka bir şey getirmediğine vurgu yapmaktadır. Şair bu tür şiirlerinde savaşın felâketini tabiat yoluyla; devrilen ağaçlarla ve kanadı kırılan kuşlarla ifade etmeye çalışmıştır (Толгуров, 1978: 57).

Kerim Otar'ın savaşla ilgili derin bir anlam ve duygu yüklü şiirlerinde estetik kaygıyı da elden bırakmadığı dikkat çekmektedir. Mesela "Uruşnu Bir Suratı" (Savaşın 
Bir Fotoğrafi) başlıklı şiirinde savaştan, sıcak bir çatışmanın hemen sonrasında kısa bir enstantane tasviri hakikaten çok çarpıcıdır. Diğer şairlerin benzer temada yazdıkları “marş” özelliğindeki şiirleriyle mukayese edildiğinde, Kerim Otar’ın özellikle de bu şiiri, gerek edebî anlamda, gerekse savaşın gerçekliğini ifade bakımından oldukça yüksek bir seviyededir. Hatta diyebiliriz ki, Kerim Otar'ın bu şiiri, bütün Sovyet edebiyatı çapında savaş temalı eserlerin içerisinde en güzel şiirlerden biridir (Отарланы, 1997: 159):

Cay künnü çığarın saklay, şoş kalkuv

Etedile tüzde Orus elçikle

Kaynağan kazanlaça köksül tılpuv

Cayadıla çuññurlarda kölçükle

Subay ak kayınçı, belinden sınıb

Catadı, top-ok üzüp, andan azçık

Arlakda, taş 1şı̆̆ına kısılıb

Caññ kança, kızaradı gül hansçık

Soldat a, bir eski işin etgença

Olturub baylaydı caññ carasin

Ayıralmazsa, saban çek ötgença

Caşav bla ölümnü arasın.
Yaz güneşinin doğmasını beklerken, sessizce Uyukluyor bozkırda küçük Rus köyleri

Kaynayan kazanlarınki gibi mavimsi buhar

Yayıyor çukurlardaki su birikintileri

Zarif kayın ağacı belinden kırılmış

Yatıyor, şarapnel parçalamış, onun biraz Ötesinde, sığınak olmuş, taşın bir kenarı Taze kan gibi, kızarıyor bir gül fidanı

Asker ise mutat bir iş yapıyormuş gibi Oturmuş bağlıyor taze yarasını Ayırmazsın, iki tarla arasındaki sınır gibi Hayat ile ölümün arasını.

\section{Sonuç: "Acı Son"}

Bu çalışmada yukarıda da ifade edildiği üzere Rusya ve eski SSCB ülkelerinin "Büyük Vatan Savaşı” şeklinde adlandırdığı, 1941-1945 yılları arasında arasında, bilhassa Nazi Almanyasına karşı topraklarını savundukları İkinci Dünya Savaşı'nın Sovyet edebiyatı üzerindeki tesiri ve buna paralel olarak da Karaçay-Malkar edebiyatındaki yansımaları, muhtelif şair ve yazarların eserlerinden de örnekler verilmek suretiyle, propaganda ve edebiyat kavramları bağlamında analiz edilmeye çalışılmıştır.

Almanların saldırısına hazırlıksız yakalanan Sovyetler Birliği, savaş için orduyu ve ekonomiyi örgütlemek, hâkimiyetindeki milletlerin maddî ve manevî desteğini almak maksadıyla yoğun bir şekilde gerçekleştirdiği propaganda faaliyetleri çerçevesinde edebiyat sahasını da etkin bir şekilde kullanmıştır. Konstantin Simonov, Nikolay Tihonov, Anna Ahmatova, İlya Ehrenburg, Aleksandir Tvardovskiy, Aleksey Surkov, Vasiliy Lebedev-Kumaç, Mihail Şolohov gibi dönemin meşhur Sovyet-Rus şair ve yazarları da dâhil olmak üzere ülkede ne kadar sanatçı varsa J. Stalin tarafından verilen direktiflerle bütün Sovyet halkını "Büyük Vatan Savaşı"na hazırlamak için seferber olmuşlar ve pek çok eser ortaya koymuşlardır. 


\section{Adilhan ADİLOĞLU, "Sovyet Propagandası Çerçevesinde İkinci Dünya Savașı'nın Karaçay-Malkar Edebiyatındaki Yansımaları”, Mavi Attas, 7(1)/2019: 16-51.}

Buna paralel olarak, Sovyetler Birliği hâkimiyetindeki Rus olmayan diğer milletlerde olduğu gibi bu dönemde Karaçay-Malkar Türklerinin edebiyatında bir "Ullu Ata Curt Kazavat" (Büyük Vatan Savaşı) teması teşekkül etmiş ve genellikle yukarıda da isimleri sayılan Sovyet-Rus şair ve yazarlarının eserleri model alınarak, başta Davut Baykul olmak üzere Hasan Bostan, Tohtar Borlak, Muhammet Orus, Abdülkerim Baykul, Halimat Bayramuk, Kaysın Kuliy, Kerim Otar ve daha pek çok Karaçay-Malkarlı şair tarafından Büyük Vatan Savaşı temalı eserler kaleme alınmıştır.

Dönemin şartlarına ve elbette Sovyet yetkililerinin verdiği direktiflere uygun olarak, Karaçay-Malkar şair ve yazarları eserlerinde genellikle Kızıl Ordunun sarsılmaz gücünü ve yenilmezliğini, Sovyet askerlerinin cehpede gösterdikleri kahramanlıklarını işlemekte, vatan topraklarının düşman işgalinden kurtuluşu için bütün Sovyet halkını maddî ve manevî desteklemeleri için seferber olmaya, gerektiğinde de vatan için canlarını feda etmeye davet etmektedirler.

Kaysın Kuliy ile Kerim Otar'ın birkaç şiiri hariç, propaganda maksadıyla ve alelacele kaleme alınmış, neredeyse tamamı birbirine benzeyen "marş" niteliğindeki bu eserlerin pek çoğu edebî bakımdan pek bir değer taşımamaktadır. Bu sebeple bunların sanattan ziyade zanaat ürünleri olduğu söylenebilir. Ancak şunu da ifade etmemiz gerekir ki, zaten bu eserler propaganda amaçlı, yani kitlelerde fikir ve tutum değişikliği yaratmak maksadıyla üretildikleri için estetik kaygı tamamiyle geri plana itilmiştir. İlya Ehrenburg'un da ifade ettiği üzere o dönemde neyin nasıl yazılacağına dair vakit olmadığ gibi, şiirde ve nesirde ancak iki renk olabilirdi: siyah ve beyaz. Bu iki rengin arasında başka renkler olamazdı. Bu sebeple o dönemdeki şair ve yazarların da sadece iki ana tema üzerine eser verebilmeleri mümkündü; bunlar da "vatan sevgisi" ile "düşmana duyulan öfke"dir (Толгуров, 1978: 34).

Öte yandan, yukarıda bolca örnekleri verilen "Büyük Vatan Savaşı" temalı eserlerin asıl maksadını; yani Almanların taarruzu üzerine büyük bir endişe ve korkuya kapılan Sovyet halklarının millî şuur ve vatan sevgisi duygularını arttırmak suretiyle onların bilhassa lojistik anlamda maddî desteğini almak, cephe gerisindeki hizmetleri gönüllülük esasına dayalı yaptırmak ve en önemlisi de Sovyet ordusunun asker kaynağının devamlılığını sağlamak gibi hedeflerini "kısmen" gerçekleştirdiği söylenebilir. Çünkü bütün bu topyekün seferberliğin gerçekleşmesindeki başarının asıl sebebi J. Stalin'in bütün Sovyet halkları üzerinde tesis ettiği “ölüm korkusu”dur. Nitekim askerlik görevinden kaçan, cepheden geri çekilen veya kaçan yüzbinlerce Sovyet askeri J. Stalin'in emriyle kurşuna dizilmiştir. Yine cephe gerisi hizmetlerden kaçan, ordunun 
lojistik ihtiyaçlarının karşılanması için çalışmak istemeyen yüzbinlerce insan Sibiryadaki çalışma kamplarına gönderilmiş ve onların da akıbetleri ölüm olmuştur. Ayrıca pek çok eserde sürekli olarak vurgulanan "Yenilmez Kızıl Ordu" da Alman orduları karşısında perişan olmuş, kısa bir süre sonra da bu propagandanın da ne kadar aldatıcı bir yalan olduğu ortaya çıkmıştır.

Esasında, Sovyetler Birliğinin savaşı kazanmasındaki en önemli etkenlerden biri de sert iklim koşullarının yanı sıra cepheye sürülen insan faktörünün sayıca fazla olmasıdır. Kendi nazarında insan hayatının kıymeti yok hükmünde olan J. Stalin savaş sırasında cephede Sovyet saflarında savaşan insanlar öldükçe onların yerine sürekli olarak insan takviyesi yapmış, hiç askerî eğitim almamış işçi ve köylüler dâhil kimi bulduysa cepheye göndermiştir. İşte bu sebepledir ki, Soyvet Birliğinin bu savaştaki insan kaybı anormal derecede çok yüksek olmuştur. Meselâ, Avrupada II. Dünya Savaşının dönüm noktası ve Sovyetlerin "Büyük Vatan Savaşı”nın büyük zaferine giden yolun başlangıcı olarak kabul edilen "Stalingrad Muharebesi"nde başta Almanya olmak üzere Mihver Devletlerinin kaybı, ölü ve yaralılar dâhil yaklaşık 500 bin ila 850 bin kişi gösterilirken, bu rakam Sovyetler Birliği için yaklaşı 1.150 bin kişidir. Bu da Sovyetlerin verdiği resmî rakamdır. Aslında bu rakamın 1.5 milyon kişiyi aştığı tahmin edilmektedir. Yani Sovyetler Birliği sadece Stalingrad Muharebesini, Mihver Devletlerin toplam kaybından iki kat daha fazla insan hayatını feda ederek kazanmıştır (Beevor, 2014: 400).

Gerek Sovyet-Rus edebiyatında ve gerekse Sovyet hâkimiyetindeki Türk halklarının edebiyatlarında Büyük Vatan Savaşıyla ilgili edebî anlamda nitelikli eserler Sovyetler Birliğinin 9 Mayıs 1945 tarihinde Almanlara karşı elde ettiği kesin zaferinden sonra verilmeye başlanmıştır. Bu tarihten sonra bütün Sovyet edebiyatında elde edilen zaferin getirdiği mutluluk temasının yanı sıra savaşın gerçek yüzü, getirmiş olduğu yıkım ve felâket üzerine psikolojik tahlillerin de yer aldığı pek çok eser ortaya konulmuştur. Ancak bu tür nitelikli eserlerin Karaçay-Malkar edebiyatında verilmeye başlanması ancak 1960’lı yılların ortalarından itibaren başlamıştır. Bunun da sebebi Karaçay-Malkar Türklerinin 1943-44 yıllarında topyekün bir şekilde ata yurtlarından Orta Asyanın muhtelif bölgelerine sürgün edilmiş olmalarıdır. On dört yıl boyunca sürgün hayatı yaşayan Karaçay-Malkar Türklerinin edebiyatı da buna bağlı olarak bu süre zarfında bir durgunluk, hatta ölü bir dönem yaşamıştır.

Karaçay-Malkar Türkleri daha "Büyük Vatan Savaşı” devam ederken J. Stalin ve L. Beriya'nın önceden kurmuş oldukları bir plan dâhilinde "Almanlarla işbirliği yapmak suretiyle vatan hainliği suçlamasıyla" topyekün bir şekilde Kazakistan, Kırgızistan ve 
Özbekistan gibi Orta Asyanın muhtelif bölgelerine dağınık olarak sürgün edilmişlerdir. Yukarıda da belirtildiği üzere, 1942 yılı Ağustos ayında Kuzey Kafkasya bölgesinin bir kısmını işgal eden Almanlar yaklaşık beş ay boyunca Karaçay-Malkar topraklarında da bulunmuşlardır. $\mathrm{Bu}$ süre zarfında bölgede yoğun bir propaganda faaliyeti yürüten Almanlar başta bu böglenin yerli halklarına Sovyet rejiminden bağımsızlık, dinî hürriyet ve özel mülkiyet gibi birtakım vaatlerde bulunarak onları Sovyet rejimine karşı isyana teşvik etmişler ve eskiden beri Sovyet rejimine karşı olan çok küçük bir kesimin desteğini almaya da muvaffak olmuşlardır. Buna karşılık halkın büyük bir kısmı Almanlarla işbirliğine yanaşmamış, tam tersine partizan (sivil direniş) birlikleri kurmak suretiyle Almanlara karşı mücadeleye girmişlerdir.

Karaçay'da ve Malkar'da Almanlarla işbirliği yapan veya onlara destek olan kişilerin toplam sayısının yaklaşık beş yüz kişi olduğu tahmin edilmektedir. Bunların yarısı savaşı kaybeden Almanlarla birlikte Kuzey Kafkasyayı terk ederek Türkiye, ABD ve Avrupa ülkelerine iltica etmişler, kalan yarısı da Sovyet yetkilileri tarafindan tutuklanarak idam edilmişlerdir. Ancak bunların da hepsi Karaçay-Malkarlı değildir. Meselâ, Almanların Karaçay’ı terk etmesinden sonra Sovyet yetkilileri tarafindan Almanlara yardım ettikleri gerekçesiyle 270 kişi tutuklanarak mahkemeye çıkarılmıştır. Bunların içinde Karaçaylıların sayısı 60 kişi olup, mahkemede suçlu bulunan Karaçaylı sayısı da sadece 6 kişidir. Görüldüğü gibi, J. Stalin ve L. Beriya'nın iddia ettiği gibi ortada bir halk1 topkeyün şekilde öz vatanından sürgün edecek bir gerekçe söz konusu değildir (Алиев, 2005: 44, 54).

Buna karşı1ık, Karaçay-Malkar Türklerinin “Büyük Vatan Savaşı”ndaki rolüne ve katkılarına gelecek olursak, ortadaki rakamlar oldukça yüksek ve hayret vericidir. Lojistik ve diğer katkıları bir tarafa, sadece Karaçay-Malkarlıların Kızıl Orduya gönderdiği asker sayısına bakalım: savaşın devam ettiği 1939-1943 yılları arasında; Kiev, Smolensk, Stalingrad, Leningrad (St. Petersburg), Dinyeper, Baltık ülkeleri, Beyaz Rusya, Polonya, Çekoslavakya, Romanya ve daha pek çok cephede Sovyet orduları safında savaşan Karaçaylı askerlerin sayısı 15.587 olup, savaşta ölenlerin sayısı da 9.078 kişidir. Aynı şekilde Malkarlı askerlerin sayısı da yaklaşık 10 bin olup, bunun 7 bini cephede hayatını kaybetmiştir. Yani toplamda Karaçay-Malkarlı askerlerin sayısı yaklaşık 25 bin kişi olup, bunun da yaklaşı 16 bini savaşta hayatını kaybetmiştir. Bu rakamlar, o dönemde nüfusu yaklaşık 140 bin olan Karaçay-Malkar Türkleri için hiç de azımsanmayacak rakamlardır (Алиев, 2005: 54). Ayrıca, on bir Karaçaylı ve iki Malkarlıya, Büyük Vatan Savaşında sadece çok üstün başarı gösterenlere verilen ve Sovyetler Birliğinin en yüksek dereceli askerî nişanı olan “Sovyetler Birliği Kahramanı” (Герой Советского Союза) madalyası 
verilmiştir. $\mathrm{Bu}$ madalyayı alan kişilerin isimleri şöyledir: Harun Bagatırov, Osman Kasayev, Hamzat Badahov, Canibek Golayev, Soltan-Hamit Biciyev, Muhammet Gerbekov, Abdullah İjayev, Ünüs Karakötov, Kiçibatır Hayırkızov, Dügerbiy Özdenov, Harun Çoçuyev (Тебуев, 1997: 320), Alim Baysultanov, Muhacir Ummayev (Сабанчиев, 2014: 159). Netice olarak rakamlar kıyaslandığı zaman, J. Stalin ile L. Beriya'nın “Almanlarla işbirliği yaptıkları” bahanesiyle Karaçay-Malkar Türklerini imha etme planı kolayca anlaşılmaktadır.

Gelelim sürgün rakamlarına; 2 Kasım 1943 tarihinde sürgün edilen Karaçaylıların sayısı 69.267 kişidir. Bu rakamın \% 54'ü çocuk, \% 28'i kadın, \% 18'i yaşlı ve savaştan dönmüş olan yaralı ve iş göremez erkeklerdir (Шаманов vd., 1993: 15). 8 Mart 1944 tarihinde sürgün edilen Malkarlıarın sayısı ise 37.713 kişidir. Bu rakamın \% 52'si çocuk, \% 30'u kadın, yüzde \% 18'i de yine yaşlı ve savaştan dönmüş olan yaralı ve iş göremez erkeklerdir. Bu rakamlara, Sovyet orduları saflarında Almanlara karşı savaşan KaraçayMalkar askerlerinin sayısı dâhil değildir ve bu askerler cephede Almanlara karşı savaşmaya devam ediyorlardı (Сабанчиев, 2014: 158).

Sürgün edilen Karaçay-Malkar Türklerine mensup ve pek çoğu da "madalyalı kahraman" olan bu askerler savaşın sona ermesinden sonra mutlu ve gururlu bir şekilde memleketlerine döndüklerinde maalesef böyle bir "acı son" ile karşılaşmışlardır. Sovyet yetkilileri bu askerlerin yüksek rütbeli olanlarının bir kısmına bazı imtiyazlar tanımışlarsa da hiçbiri bunu kabul etmeyerek kendi rızalarıyla ailelerini aramak üzere sürgüne gitmişlerdir. Savaş döneminde pek çok şair ve yazarını kaybeden Karaçay-Malkar Türklerinin on dört yıl süren sürgün hayatı boyunca tabiî olarak edebiyatı da oldukça cılız kalmıştır. Sürgün zamanında iken ancak birkaç şiir antolojisi ile Kaysın Kuliy, Kerim Otar ve İsa Botaş gibi bazı şair ve yazarların birkaç eseri yayımlanabilmiştir. Yukarıda da belirttiiğimiz gibi savaşla ilgili temaların işlendiği asıl edebî eserler Karaçay-Malkar Türklerinin 1957 yılında kendi yurtlarına dönmelerinden sonra, 1960'lı yılların ortalarından itibaren verilmeye başlanmıştır. $\mathrm{Bu}$ döneme ait edebî eserler ise bir başka çalışmamızda ele alınacaktır.

\section{Kaynakça}

АКБАЕВ, М.О., Х.Б. БАЙРАМУКОВА, Н.М. КАГИЕВА (1965). Къарачай Поезияны Антологиясы, Ставрополь Шахар: Ставрополь Китаб Издательство.

ALEKSIYYEVİÇ, Svetlana (2002). Nazi İsgalinde Sovyet Kadınları, (Çev. Serpil Güvenç, Hilal Ünlü), İstanbul: Evrensel Basım Yayım.

АЛИЕВ, Кази-Магомет (2005). В Зоне Эдельвейса, Москва-Ставрополь: Сервисшкола. 
Adilhan ADILLOĞLU, "Sovyet Propagandası Çerçevesinde İkinci Dünya Savaşı'nın Karaçay-Malkar Edebiyatındaki Yansımaları”, Mavi Attas, 7(1)/2019: 16-51.

ARMAOĞLU, Fahir (1999). 20. Yüzyll Siyasi Tarihi (1914-1995), Cilt 1-2, Genişletilmiş 11. Bask1, İstanbul: Alkım Yayınevi.

АВАНЕСЯН, Аревика Армоевна (2015). "По Страницам Газет 1941-1945 Годов”, Отечественная Война 1941-1945 г2. в Документах и Памяти Народа, (Ред. А.И. Коломыткин), Волгоград, ss. 49-52.

БАЙКЪУЛЛАНЫ, Абдулкерим (1958). Хорлам, Черкесск: Къарачай-Черкес Китаб Издательство.

БАЙКЪУЛЛАНЫ, Даут (1959). Джазгъанларыны Сайламалары, Черкесск: Къарачай-Черкес Китаб Издательство.

БАЙРАМУКЪЛАНЫ, Халимат (1963). Залихат, Черкесск: Къарачай-Черкес Китаб Издательство.

BEEVOR, Antony (2014), Stalingrad, (Çev. Nurettin Elhüseyni), İstanbul: YKY.

БАЙРАМУКЪЛАНЫ, Халимат (2008). Джскъдан Бар Болуб Къалсам Бир Кюнде, (Хаз. Байрамукъланы Фатима, Къобанланы Земфира), Москва: Элбрусоид Басма.

БЛИМГОЛАНЫ, М., Р. ЛАЙПАНЛАНЫ (1975). “Ленинни БайрагъЫ: Туугъаны эм да Ёсюм Джолу”, Заманны Aуазы: Къарачай Джазыучула бла Илму Къуллукъчуланы Чызъармаларыны Джыйымдыгъы,, Черкесск: Ставрополь Китаб Басманы Къарачай-Черкес Бёлюмю, ss. 152-184.

БОРЛАКЪЛАНЫ, Тохдар (1939). Насыблы Джашлыкъ, Микоян-Шахар: Къарачай Областны Национальный Издательствосу.

БОСТАНЛАНЫ, Хасан (1962). Сайламалары, Черкесск: Къарачай-Черкес Китаб Исдательство.

БУДАЕВ, Азрет (1976). Ата Журтум, Нальчик: Эльбрус Китап Басма.

CAN, Badegül (2012). "Büyük Vatan Savaşının Gölgesinde Rus Edebiyatına Bakış”, Avrasya Uluslararası Araştırmalar Dergisi, Sayı:1, ss. 42-49.

CİGITOV, Salican (2004). "Cengiz Aytmatov Edebiyat Meydanında Yeni Boy Gösterdiğinde”, Cengiz Aytmatov: Doğumunun 75. Yılı için Armağan, Bişkek: KırgızistanTürkiye Manas Üniversitesi Yayınları.

ГУРТУЕВ, Берт (1958). Жарык Танг, Нальчик: Къабарты-Малкъар Китаб Басмасы.

GÜVENIR, Esra ve Şevval PARLAK (2018). “Josef Stalin'in 3 Temmuz 1941 Savaş Konuşması", Pravda Gazetesi, 3 Temmuz 1941, (Rusça Aslından Çevirenler: Esra Güvenir, Şevval Parlak), Tarihlerle.com, Erişim Tarihi: 25.12.2018, (https://tarihlerle.com/josefstalin-in-3-temmuz-1941-savas-konusmasi).

HART, Basil Liddell (2015). İkinci Dünya Savaşı Tarihi, (Çeviren: Kerim Bağrıaçık), İstanbul: Türkiye İş Bankası Kültür Yayınları.

HİKMET, Nazım (2008). Bütün Şiirleri, (4. Bask1), İstanbul: YKY. 
Adilhan ADİLOĞLU, “Sovyet Propagandası Çerçevesinde İkinci Dünya Savaşı’nın Karaçay-Malkar Edebiyatındaki Yansımaları”, Mavi Attas, 7(1)/2019: 16-51.

ХОЧУЕВ, Салих (1986). Хапарла, (Хаз. Биттирланы Тамара), Нальчик: Элбрус Китап Басма.

ХУБИЙЛАНЫ, Осман (1963). Ант, Черкесск: Къарачай-Черкес Китаб Издательство.

ИНБЕР, Вера (1954). Стихотворения, Москва: Государственное Издательство Художественной Литературы.

КЪАГЪЫЙЛАНЫ, Назифа (1975). “Джигитликни Адети”, Заманны Ауазы: Къарачай Джазыучула бла Илму Къуллукъчуланы Чыгъармаларыны Джыйымдыгъы, Черкесск: Ставрополь Китаб Басманы Къарачай-Черкес Бёлюмю, ss. 117-141.

КАРАЕВА, А.И. (1966). Очерк Истории Карачаевской Литературы, Москва: Издательство Наука.

КЪАРАЛАНЫ, Асият (1978). “Къарачай Литературада Уллу Ата Джурт Къазауатны Темасы”, Излем: Къарачай Дюсаи Джазыучула бла Илму Къуллукъчуланы Чьюгъармалары, Черкесск: Ставрополь Китаб Басманы Къарачай-Черкес Бёлюмю, ss. 192-217.

КЪАРАЛАНЫ, А.И. (1996). Къарачай Литератураны Историясыны Очерки, Черкесск: Къарачай-Черкес Республика Китаб Басмасы.

КЪАРАЛАНЫ, А.И., Д.Б. БОРЛАКЪЛАНЫ (1972). Къарачай Литература, Черкесск: Ставрополь Китаб Издательтвону Къарачай-Черкес Бёлюмю.

КЪАРАЛАНЫ, А.И., Д.Б. БОРЛАКЪЛАНЫ (1984). Къарачай Литература, Черкесск: Ставрополь Китаб Басманы.

КЪАРАЛАНЫ, А.И., Д.Б. БОРЛАКЪЛАНЫ (1987). Къарачай Литература, Черкесск: Ставрополь Китаб Басманы Къарачай-Черкес Бёлюмю.

КЪАРАЛАНЫ, А.И., Д.Б. БОРЛАКЪЛАНЫ (1990). Къарачай Литература, Черкесск: Ставрополь Китаб Басманы.

КЪАСАЙЛАНЫ, Роза (1974). Джигитликни Дюырчысы, Черкесск: Ставрополь Китаб Басманы.

КЪАЗАЛЫЛАНЫ, А.К. (1982). Къарачай Литератураны Дерслеринде Социалист Гуманизмге Юретиу, Черкесск: Ставрополь Китаб Басманы.

КУЛИЕВ, Къайсын (1958). Сайлама: Эки Томлукъ, Биринчи Тому, Нальчик: Къабарты-Малкъар Китаб Басмасы.

МАГУЛАЕВА, Фатима (2010). Становление и Развитие Прессы Карачая (19181959 гz.), Ставрополь: Издательство Ставропольского Государственного Университета.

МАКИТОВ, Сафар (1958). Шаудан, Нальчик: Къабарты-Малкъар Китаб Басмасы.

MAMMEEB, Д. (1978). “Малкъар Литературада Уллу Ата Журт Урушну Жылларында", Малкъар Литератураны Историясыны Очерклери, (Ред. Джулабов, У.А.), Нальчик: Эльбрус Китап Басма, ss. 122-138.

МЕЧИЛАНЫ, Каิзим (1989). Чьъъармаларыны Экитомлугъу: Экинчи Тому, (Хаз. Алим Теппеев), Нальчик: Эльбрус Китап Басма. 
Adilhan ADILLOĞLU, "Sovyet Propagandası Çerçevesinde İkinci Dünya Savaşı'nın Karaçay-Malkar Edebiyatındaki Yansımaları”, Mavi Attas, 7(1)/2019: 16-51.

ОТАРЛАНЫ, Керим (1997). Сайламала, (Хаз. Мокъаланы Магомет, Отарланы Римма), Нальчик: Эльбрус Китап Басма.

ЁРТЕНЛАНЫ, Азрет (1959). Джазгъанларыны Сайламалары, Черкесск: Къарачай-Черкес Китаб Издательство.

САБАНЧИЕВ, Х.М.А. (2014), “Депортация Балкарского Народа и Ее Последствия", Горы Молчат, Но Помнят: Материалы Всероссийской НаучноТеоретической Конференщии Посвященной 70-Летийю дня Депортации Балкарского Народа, Нальчик: Полиграфисервис в Т.

SINAR UĞURLU, Alev (2009). “Türk Romancısının Gözüyle II. Dünya Savaşı”, Turkish Studies, Say1: 4/1-II, ss. 1739-1764.

СИНЯВСКИЙ, А.Д. (1961). “Литература Периода Великой Отечественной Войны”, История Русской Советской Литературы, (Ред. Дементев, А.Г.), Том: 3, Москва: Издательство Академик Наук ССCP, ss. 5-53.

ШАХМУРЗАЕВ, Саид (1957). Сырыйна, Нальчик: Къабарты-Малкъар Китаб Басмасы.

ШАМАНОВ, И.М., З.Б. КАРАЕВА, К.А. КЕЧЕРУКОВ, А.М.Ч. АЛИЕВ (1993), Карачаевиы Выселение и Возвращение, Черкесск: Издательство Пул.

ТЕБУЕВ, Рамазан (1997), Депортация Карачаевцев, Черкесск.

ТИХОНОВ, Николай (1943). Красной Армии, Ленинград: Государственное Издательство Художественной Литературы.

ТОХЧУКОВ, Х. (1941). Ата Джурт Ючюн Алгъа: Къарачай Поэтлени Джырлары, Микоян-Шахар: Къароблмиллетиздательство.

ТОЛГУРОВ, Зейтун (1978). Заман бла Литература, Нальчик: Эльбрус Китап Басма.

TÜRKER, Ferah (2012). "II. Dünya Savaşının Modern Altay Edebiyatına Yansımaları", Türk Dünyası Incelemeleri Dergisi, Sayı: XII/1, ss. 331-344.

УРУСБИЕВА, Ф. (1978). “Хорлагъан Социализмни Литературасы”, Малкъар Литератураны Историясыны Очерклери (Ред. Джулабов, У.А.), Нальчик: Эльбрус Китап Басма, ss. 102-122.

ЯЦЫНОВ, П. (1943). Армии Нашей, Ленинград: Военное Издательство Народного Комиссариата Обороны. 